DOE/ID-22208

Prepared in cooperation with the U.S. Department of Energy

\title{
lodine-129 in the Snake River Plain Aquifer at and Near the Idaho National Laboratory, Idaho, 2003 and 2007
}

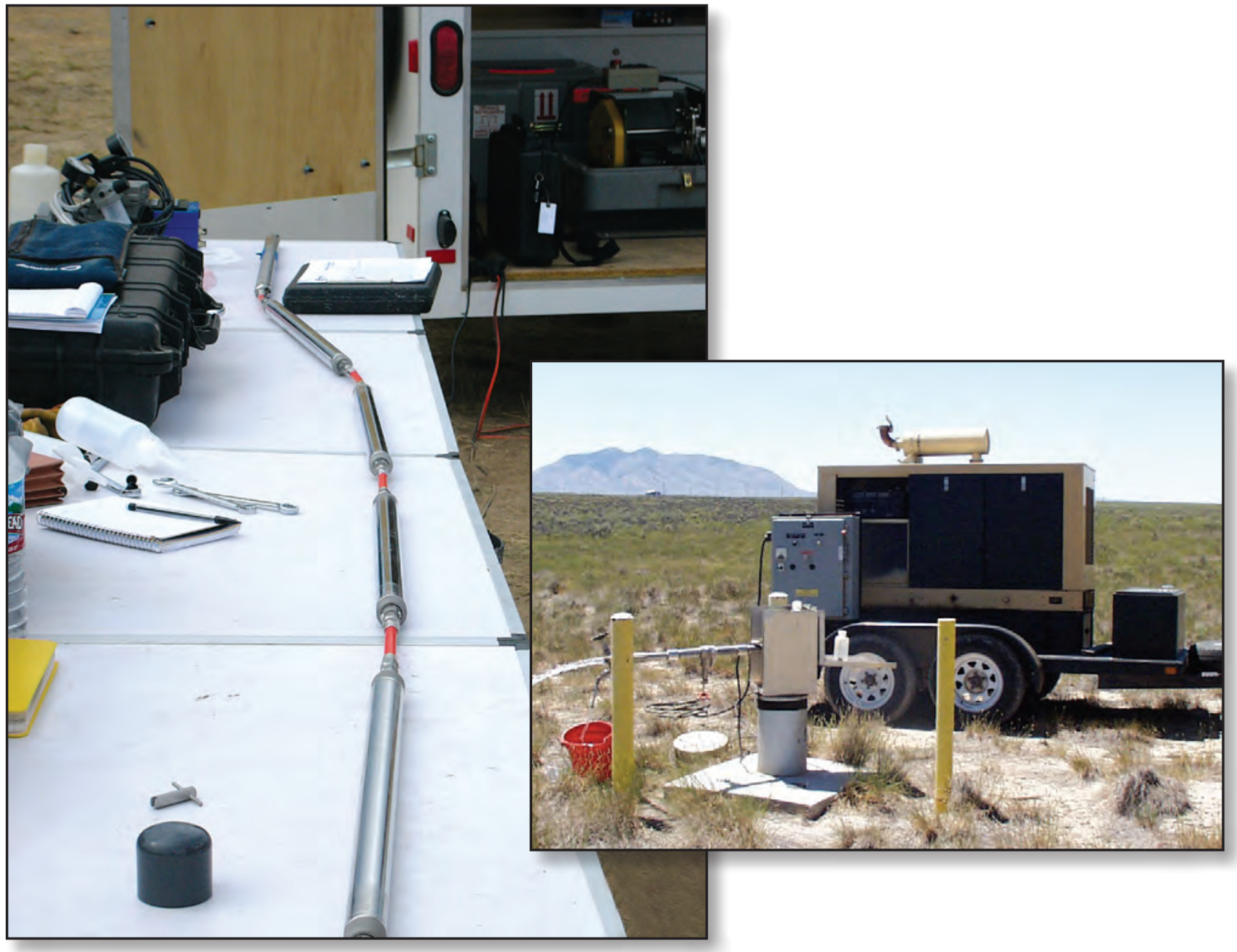

Scientific Investigations Report 2009-5088 
Cover: Photographs (from left to right) of sample collection equipment and U.S. Geological Survey pumping well. (Photograph courtesy of the U.S. Geological Survey, Idaho National Laboratory Project Office.) 


\section{lodine-129 in the Snake River Plain Aquifer at and Near the Idaho National Laboratory, Idaho, 2003 and 2007}

By Roy C. Bartholomay

Prepared in cooperation with the U.S. Department of Energy

Scientific Investigations Report 2009-5088 


\title{
U.S. Department of the Interior \\ KEN SALAZAR, Secretary \\ U.S. Geological Survey \\ Suzette M. Kimball, Acting Director
}

\section{U.S. Geological Survey, Reston, Virginia: 2009}

\author{
For more information on the USGS — the Federal source for science about the Earth, its natural and living resources, \\ natural hazards, and the environment, visit http://www.usgs.gov or call 1-888-ASK-USGS \\ For an overview of USGS information products, including maps, imagery, and publications, \\ visit http://www.usgs.gov/pubprod \\ To order this and other USGS information products, visit http://store.usgs.gov
}

\begin{abstract}
Any use of trade, product, or firm names is for descriptive purposes only and does not imply endorsement by the U.S. Government.

Although this report is in the public domain, permission must be secured from the individual copyright owners to reproduce any copyrighted materials contained within this report.
\end{abstract}

Suggested citation:

Bartholomay, R.C., 2009, lodine-129 in the Snake River Plain aquifer at and near the Idaho National Laboratory, Idaho, 2003 and 2007: U.S. Geological Survey Scientific Investigations Report 2009-5088, 28 p. 


\section{Contents}

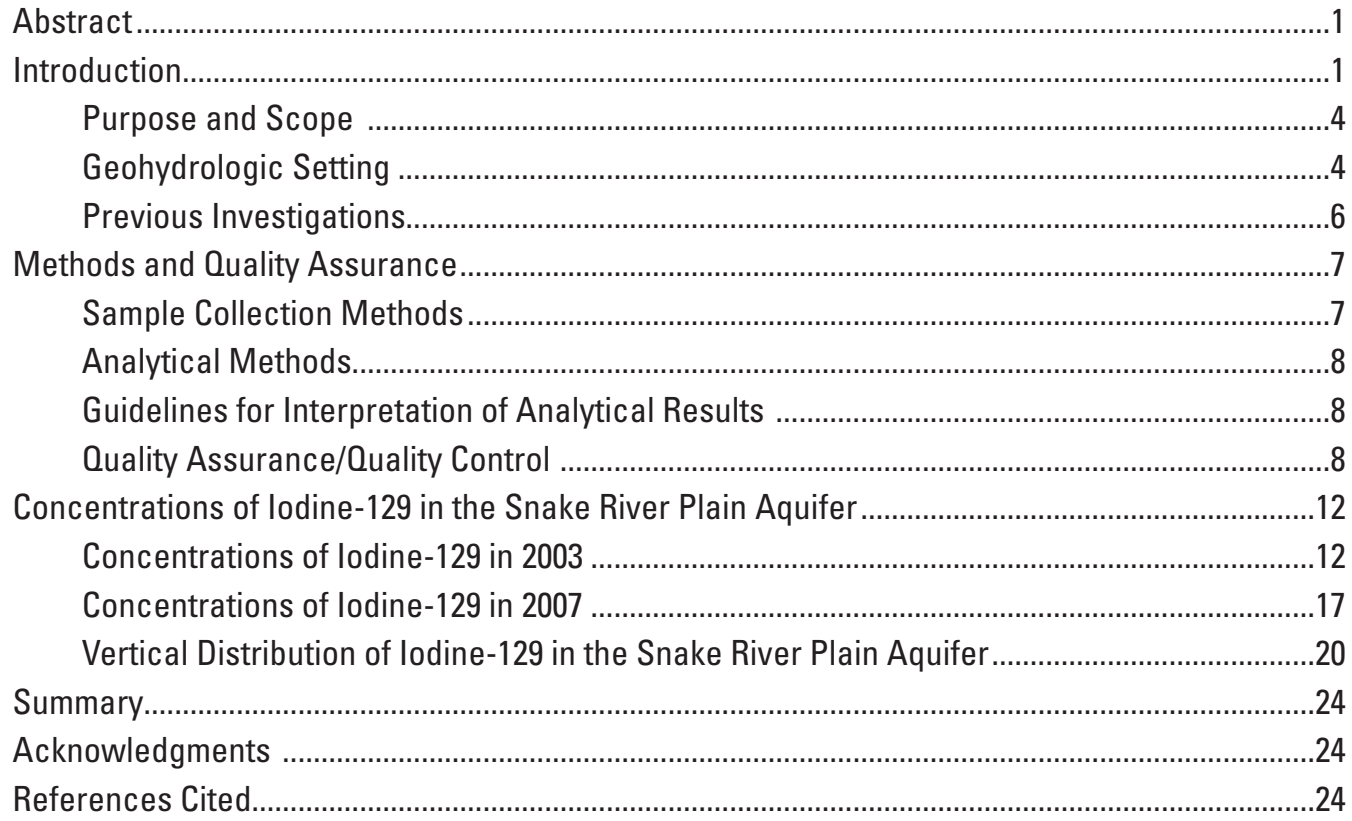

\section{Figures}

Figure 1. Map showing location of the Idaho National Laboratory, Idaho $\ldots \ldots \ldots \ldots \ldots \ldots .2$

Figure 2. Map showing location of wells at and near the Idaho National Laboratory,

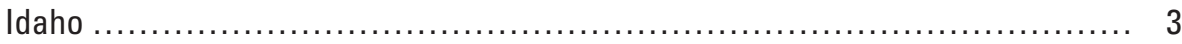

Figure 3. Map showing location of wells near the Idaho Nuclear Technology and Engineering Center, Idaho National Laboratory, Idaho

Figure 4. Map showing areal distribution of iodine-129 in the Snake River Plain aquifer at the Idaho National Laboratory, Idaho, 2003

Figure 5. Map showing change in concentration of iodine-129 between samples collected from selected wells, Idaho National Laboratory, Idaho, 1990-91 and 2003

Figure 6. Map showing areal distribution of iodine-129 in the Snake River Plain aquifer at the Idaho National Laboratory, Idaho, 2007

Figure 7. Map showing change in concentration of iodine-129 between water samples from wells at the Idaho National Laboratory, Idaho, 2003 and 2007

Figure 8. Graph showing concentrations of iodine-129 in well Middle 2051 in relation to piezometric head, Idaho National Laboratory, Idaho, 2007 


\section{Tables}

Table 1. Concentrations of iodine-129 in ground water, Idaho National Laboratory, Idaho, 2003 and 2007

Table 2. Concentrations of iodine-129 at multiple aquifer depths, Idaho National Laboratory, Idaho, 2007.

Table 3. Concentrations of iodine-129 in water from selected wells, Idaho National Laboratory, Idaho, 1990-91, 2003, and 2007

Table 4. Concentrations of chloride, iodine-129, sodium, and strontium-90 in water from selected wells, Idaho National Laboratory, Idaho, 2003 and 2007

Table 5. Concentrations of selected chemicals at multiple aquifer depths, Idaho National Laboratory, Idaho

\section{Conversion Factors, Datums, and Abbreviations and Acronyms}

\begin{tabular}{lcl}
\multicolumn{1}{c}{ Conversion Factors } & & \\
\hline \multicolumn{1}{c}{ Multiply } & By & \multicolumn{1}{c}{ To obtain } \\
\hline acre & 4,047 & square meter $\left(\mathrm{m}^{2}\right)$ \\
acre-foot (acre-ft) & 1,233 & cubic meter $\left(\mathrm{m}^{3}\right)$ \\
cubic foot per second $\left(\mathrm{ft}^{3} / \mathrm{s}\right)$ & 0.02832 & cubic meter per second $\left(\mathrm{m}^{3} / \mathrm{s}\right)$ \\
foot (ft) & 0.3048 & meter $(\mathrm{m})$ \\
foot per day $(\mathrm{ft} / \mathrm{d})$ & 0.3048 & meter per day $(\mathrm{m} / \mathrm{d})$ \\
foot per mile $(\mathrm{ft} / \mathrm{mi})$ & 0.1894 & meter per kilometer $(\mathrm{m} / \mathrm{km})$ \\
foot per second $(\mathrm{ft} / \mathrm{s})$ & 0.3048 & meter per second $(\mathrm{m} / \mathrm{s})$ \\
foot squared per day $\left(\mathrm{ft}^{2} / \mathrm{d}\right)$ & 0.09290 & meter squared per day $\left(\mathrm{m}^{2} / \mathrm{d}\right)$ \\
gallon $($ gal) & 3.785 & liter $(\mathrm{L})$ \\
gallon per minute $(\mathrm{gal} / \mathrm{min})$ & 0.06309 & liter per second $(\mathrm{L} / \mathrm{s})$ \\
mile $($ mi) & 1.609 & kilometer $(\mathrm{km})$ \\
ounce, avoirdupois $(\mathrm{oz} \mathrm{avdp})$ & 28.32 & gram $(\mathrm{g})$ \\
picocurie per liter $(\mathrm{pCi} / \mathrm{L})$ & 0.037 & becquerel per liter $(\mathrm{Bq} / \mathrm{L})$ \\
attocurie per liter $(\mathrm{aCi} / \mathrm{L})$ & $3.7 \times 10^{-8}$ & becquerel per liter $(\mathrm{Bq} / \mathrm{L})$ \\
square mile $\left(\mathrm{mi}^{2}\right)$ & 2.590 & square kilometer $\left(\mathrm{km}{ }^{2}\right)$
\end{tabular}

Temperature in degrees Celsius $\left({ }^{\circ} \mathrm{C}\right)$ may be converted to degrees Fahrenheit $\left({ }^{\circ} \mathrm{F}\right)$ as follows:

$$
{ }^{\circ} \mathrm{F}=\left(1.8 x^{\circ} \mathrm{C}\right)+32 .
$$

Specific conductance is given in microsiemens per centimeter at 25 degrees Celsius $\left(\mu \mathrm{S} / \mathrm{cm}\right.$ at $\left.25^{\circ} \mathrm{C}\right)$.

Concentrations of chemical constituents in water are given either in milligrams per liter (mg/L) or micrograms per liter ( $\mu \mathrm{g} / \mathrm{L})$. 
Datums

Vertical coordinate information is referenced to National Geodetic Vertical Datum of 1929 (NGVD 29).

Horizontal coordinate information is referenced to North American Datum of 1927 (NAD 27).

Altitude, as used in this report, refers to distance above the vertical datum.

Abbreviations and Acronyms

\begin{tabular}{ll}
\multicolumn{1}{c}{$\begin{array}{c}\text { Abbreviation or } \\
\text { Acronym }\end{array}$} & \multicolumn{1}{c}{ Definition } \\
\hline I29 & lodine-129 \\
AMS & accelerator mass spectrometer \\
CFA & Central Facilities Area \\
Ci & curie \\
DOE & U.S. Department of Energy \\
ESRP & eastern Snake River Plain \\
INL & Idaho National Laboratory \\
INTEC & Idaho Nuclear Technology and Engineering Center \\
MCL & maximum contaminant level \\
RTC & Reactor Technology Complex \\
PRIME & Purdue Rare Isotope Measurement \\
USEPA & U.S. Environmental Protection Agency \\
USGS & U.S. Geological Survey \\
\hline
\end{tabular}


This page intentionally left blank. 


\title{
lodine-129 in the Snake River Plain Aquifer at and Near the Idaho National Laboratory, Idaho, 2003 and 2007
}

\author{
By Roy C. Bartholomay
}

\section{Abstract}

From 1953 to 1988, wastewater containing approximately 0.94 curies of iodine- $129\left({ }^{129} \mathrm{I}\right)$ was generated at the Idaho National Laboratory (INL) in southeastern Idaho. Almost all of this wastewater was discharged at or near the Idaho Nuclear Technology and Engineering Center (INTEC) on the INL site. Most of the wastewater was discharged directly into the eastern Snake River Plain aquifer through a deep disposal well until 1984; however, some wastewater also was discharged into unlined infiltration ponds or leaked from distribution systems below the INTEC.

In 2003, the U.S. Geological Survey (USGS), in cooperation with the U.S. Department of Energy, collected samples for ${ }^{129}$ I from 36 wells used to monitor the Snake River Plain aquifer, and from one well used to monitor a perched zone at the INTEC. Concentrations of ${ }^{129} \mathrm{I}$ in the aquifer ranged from $0.0000066 \pm 0.0000002$ to $0.72 \pm 0.051$ picocuries per liter $(\mathrm{pCi} / \mathrm{L})$. Many wells within a 3-mile radius of the INTEC showed decreases of as much as one order of magnitude in concentration from samples collected during 1990-91, and all of the samples had concentrations less than the Environmental Protection Agency's Maximum Contaminant Level (MCL) of $1 \mathrm{pCi} / \mathrm{L}$. The average concentration of ${ }^{129} \mathrm{I}$ in 19 wells sampled during both collection periods decreased from $0.975 \mathrm{pCi} / \mathrm{L}$ in $1990-91$ to $0.249 \mathrm{pCi} / \mathrm{L}$ in 2003 . These decreases are attributed to the discontinuation of disposal of ${ }^{129} \mathrm{I}$ in wastewater after 1988 and to dilution and dispersion in the aquifer.

Although water from wells sampled in 2003 near the INTEC showed decreases in concentrations of ${ }^{129} \mathrm{I}$ compared with data collected in 1990-91, some wells south and east of the Central Facilities Area, near the site boundary, and south of the INL showed slight increases. These slight increases may be related to variable discharge rates of wastewater that eventually moved to these well locations as a mass of water from a particular disposal period.

In 2007, the USGS collected samples for ${ }^{129}$ I from 36 wells that are used to monitor the aquifer south of INTEC and from 2 wells that are used to monitor perched zones at INTEC. Concentrations of ${ }^{129} \mathrm{I}$ in the eastern Snake River Plain aquifer ranged from $0.000026 \pm 0.000002$ to $1.16 \pm 0.04 \mathrm{pCi} / \mathrm{L}$, and the concentration at one well exceeded the maximum contaminant level $(1 \mathrm{pCi} / \mathrm{L})$ for public drinking water supplies. The average concentration of 19 wells sampled in 2003 and 2007 did not differ; however, slight increases and decreases of concentrations in several areas around the INTEC were evident in the aquifer. The decreases are attributed to the discontinued disposal and to dilution and dispersion in the aquifer. The increases may be due to the movement into the aquifer of remnant perched water below the INTEC.

In 2007, the USGS also collected samples from 31 zones in 6 wells equipped with multi-level Westbay ${ }^{\mathrm{TM}}$ packer sampling systems to help define the vertical distribution of ${ }^{129} \mathrm{I}$ in the aquifer. Concentrations ranged from 0.000011 \pm 0.0000005 to $0.0167 \pm 0.0007 \mathrm{pCi} / \mathrm{L}$. For three wells, concentrations of ${ }^{129} \mathrm{I}$ between zones varied one to two orders of magnitude. For two wells, concentrations varied for one zone by more than an order of magnitude from the wells' other zones. Similar concentrations were measured from all five zones sampled in one well. All of the 31 zones had concentrations two or more magnitudes below the maximum contaminant level.

\section{Introduction}

The Idaho National Laboratory (INL), encompassing about $890 \mathrm{mi}^{2}$ of the eastern Snake River Plain (ESRP) in southeastern Idaho (fig. 1), is operated by the U.S. Department of Energy (DOE). The INL was established in 1949 for the development of peacetime atomic energy applications, nuclear safety research, defense programs, environmental research, and advanced energy concepts. Until 1993, uranium from spent nuclear fuel elements from government-owned reactors was recovered after reprocessing at the Idaho Nuclear Technology and Engineering Center (INTEC, fig. 1). As part of the fuel reprocessing activities, several fission products were released in wastewater at the INTEC. Iodine-129 ( $\left.{ }^{129} \mathrm{I}\right)$, produced by the fission of uranium-235 and plutonium-239, was one of the products released in wastewater. Prior to 1984 , most of the wastewater generated at the INTEC was injected directly to the ESRP aquifer through a 598-ft-deep disposal well. Beginning in February 1984, routine use of the disposal well was discontinued, and wastewater was discharged to unlined infiltration ponds (fig. 2), which allow the wastewater 

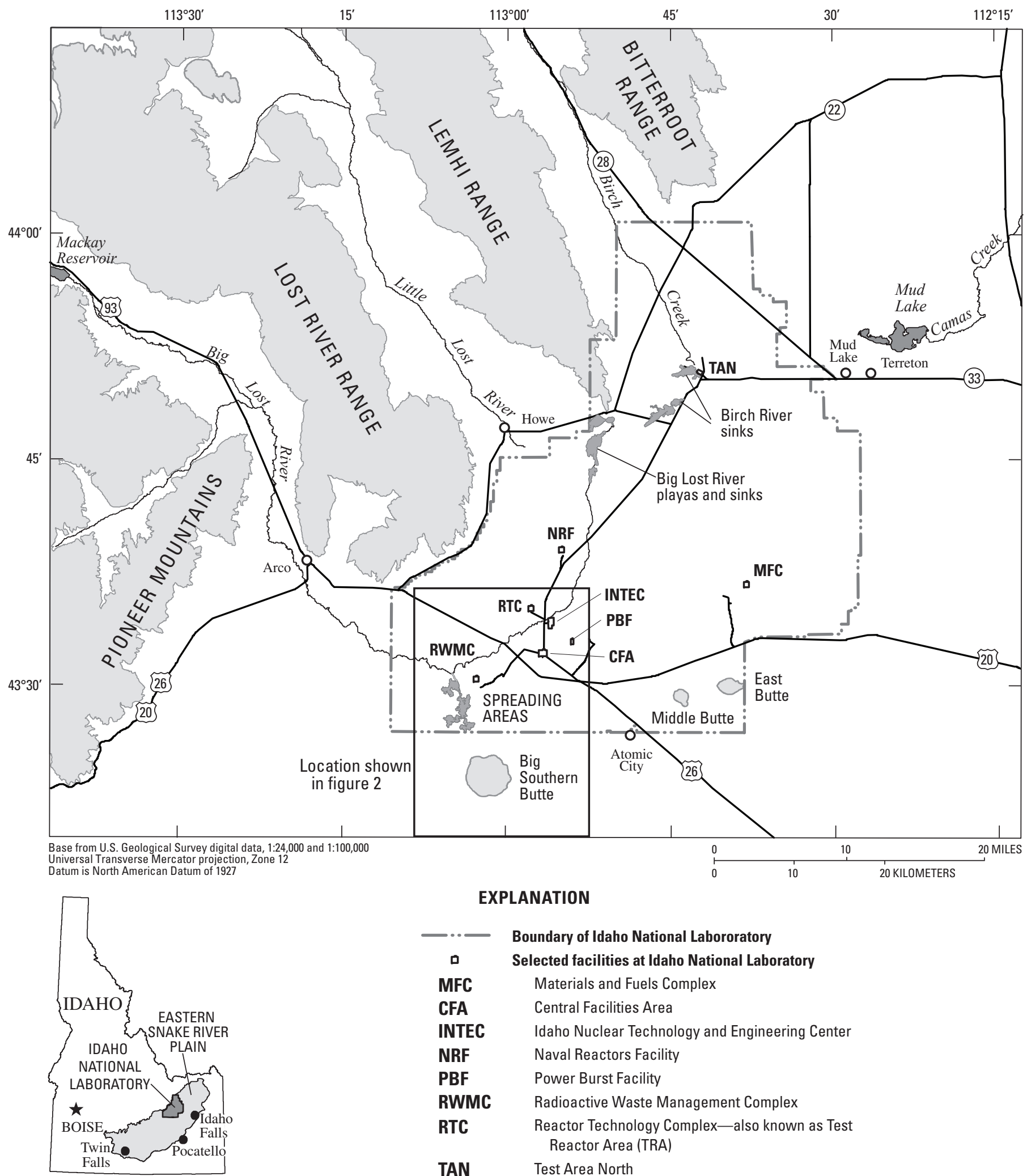

\begin{tabular}{cc}
$-\cdots$ & Boundary of Idaho National Labororatory \\
\hline MFC & Selected facilities at Idaho National Laboratory \\
CFA & Materials and Fuels Complex \\
INTEC & Central Facilities Area \\
NRF & Idaho Nuclear Technology and Engineering Center \\
PBF & Power Burst Facility \\
RWMC & Radioactive Waste Management Complex \\
RTC & Reactor Technology Complex-also known as Test \\
& Reactor Area (TRA) \\
TAN & Test Area North
\end{tabular}

Figure 1. Location of the Idaho National Laboratory, Idaho. 


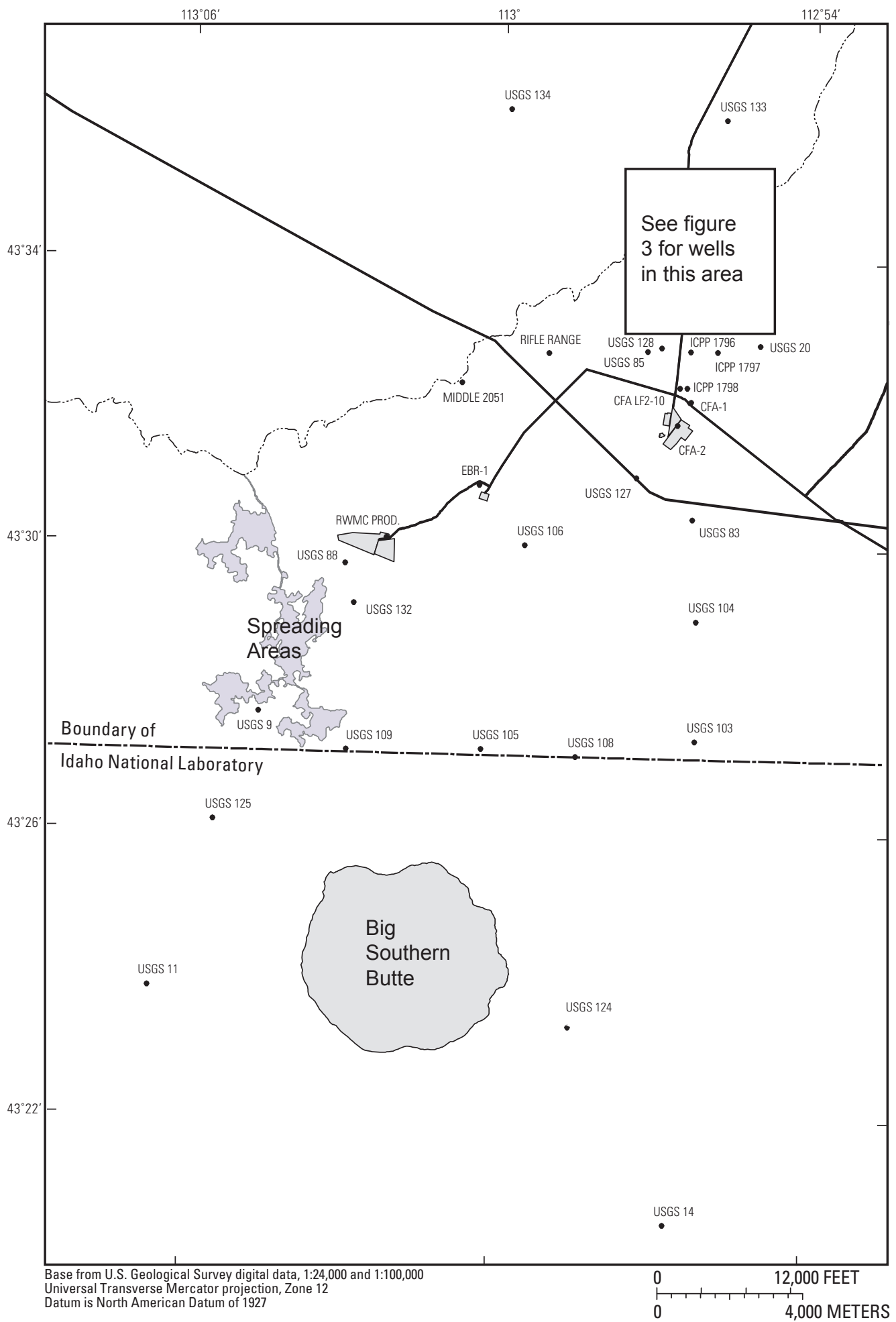

Figure 2. Location of wells at and near the Idaho National Laboratory, Idaho. 
to percolate through about $450 \mathrm{ft}$ of basalt and sediment to the aquifer.

Iodine-129 in the ESRP aquifer originates from atmospheric deposition, rock weathering, and wastewater disposal (Mann and Beasley, 1994a). The amount of ${ }^{129} \mathrm{I}$ in the aquifer from atmospheric deposition and rock weathering is considered small, and is included in the estimated background concentration of 0.0000054 picocuries per liter $(\mathrm{pCi} / \mathrm{L})$ in the ESRP aquifer in eastern Idaho (Cecil and others, 2003). Mann and Beasley (1994a) reported that wastewater discharged to the injection well and infiltration ponds at the INTEC between 1953 and 1990 contained an estimated $0.56-1.18$ curies (Ci) of ${ }^{129} \mathrm{I}$. A more detailed estimate of wastewater discharge was performed by the DOE Idaho Operations Office (U.S. Department of Energy, 2004, appendix D), and results indicated that a maximum of $0.86 \mathrm{Ci}$ of ${ }^{129} \mathrm{I}$ was discharged to the aquifer through the injection well. In addition, about $0.08 \mathrm{Ci}$ of ${ }^{129} \mathrm{I}$ were discharged to the infiltration ponds from 1984 to 1988 (Litteer, 1988; Mann and others, 1988, table 2; Litteer and Reagan, 1989), and about 0.001 Ci of iodine-129 was released at the INTEC Tank Farm (fig. 3) between 1958 and 1986 (Cahn and others, 2006, table 5-2). Therefore, some ${ }^{129}$ I may still be present in perched zones around the INTEC. Some ${ }^{129} \mathrm{I}$ also was discharged into the radioactive waste ponds at the Reactor Technology Complex (RTC), but annual concentrations of the discharge water generally were much less than a pCi/L; for example EG\&G Idaho, Inc. (1979) showed an average annual concentration of $12.8 \times 10^{-6} \mathrm{pCi} / \mathrm{L}$ in the 1978 discharge water. Because of its 15.7 million-year half-life, ${ }^{129}$ I released to the environment is a permanent addition to the global inventory (Mann and others, 1994a).

Given that ${ }^{129} \mathrm{I}$ is a known carcinogen, there is concern that its disposal at the INL might pose a health hazard to downgradient communities. The current (1976) U.S. Environmental Protection Agency maximum contaminant level (MCL) for ${ }^{129} \mathrm{I}$ in drinking water is $1 \mathrm{pCi} / \mathrm{L}$ (U.S. Environmental Protection Agency, 1976, Appendix B). The MCL is based on the average concentration in public drinking water supplies that will yield an annual whole-body dose equivalent to 4 millirem for man-made beta-particle and photon-emitting radiounuclides; the proposed MCL based on effective dose equivalent for ${ }^{129} \mathrm{I}$ is $21 \mathrm{pCi} / \mathrm{L}$ (U.S. Environmental Protection Agency, 2000). To evaluate the potential hazards, the U.S. Geological Survey (USGS) in cooperation with the DOE, have periodically monitored for ${ }^{129} \mathrm{I}$ in ground water from the ESRP aquifer at and downgradient of the INTEC since 1977. Monitoring programs from 1977, 1981, 1986 and 1990-91 were summarized by Mann and others (1988) and by Mann and Beasley (1994b). This report summarizes concentrations in the aquifer in 2003 and 2007.

\section{Purpose and Scope}

The USGS collected water samples from wells during 2003 and 2007 to evaluate recent concentrations of ${ }^{129} \mathrm{I}$ in the ESRP aquifer. This report describes the results of water samples collected for ${ }^{129}$ I analyses (41 samples in 2003 and 75 samples in 2007).

In 2003, samples were collected from 36 wells that are used to monitor the ESRP aquifer and from 1 well that is used to monitor a perched zone at the INTEC. Four replicate samples were collected as a measure of quality assurance/ quality control (QA/QC).

In 2007, samples were collected from 31 zones in 6 wells equipped with multi-level Westbay ${ }^{\mathrm{TM}}$ packer sampling systems. In addition, samples were submitted for analyses from 36 other wells that are used to monitor the aquifer south of the INTEC and from 2 wells that are used to monitor perched zones at the INTEC. Three samples were collected as QA/QC replicates, and three samples were collected as $\mathrm{QA} / \mathrm{QC}$ equipment blanks. The wells were sampled to determine the current concentrations in the ESRP aquifer. Those concentrations were compared with past data to determine concentration changes.

\section{Geohydrologic Setting}

The INL is located above the west-central part of the ESRP. The ESRP is a northeast-trending structural basin about 200-mi long and 50-70 mi wide (fig. 1). The basin, bounded by faults on the northwest and by downwarping and faulting on southeast, has been filled with basaltic lava flows interbedded with terrestrial sediments. The basaltic rocks and sedimentary deposits combine to form the ESRP aquifer, which is the main source of ground water on the plain.

The ESRP aquifer is one of the most productive aquifers in the United States (U.S. Geological Survey, 1985, p. 193). Movement of water in the aquifer generally is from northeast to southwest, and water eventually discharges to springs along the Snake River downstream of Twin Falls, Idaho-about $100 \mathrm{mi}$ southwest of the INL. Water moves horizontally through basalt interflow zones and vertically through joints and interfingering edges of interflow zones. Infiltration of surface water, heavy pumpage, geologic conditions, and seasonal fluxes of recharge and discharge locally affect the movement of ground water (Garabedian, 1986). Recharge to the ESRP aquifer is primarily from infiltration of applied irrigation water, infiltration of streamflow, ground-water inflow from adjoining mountain drainage basins, and infiltration of precipitation. 


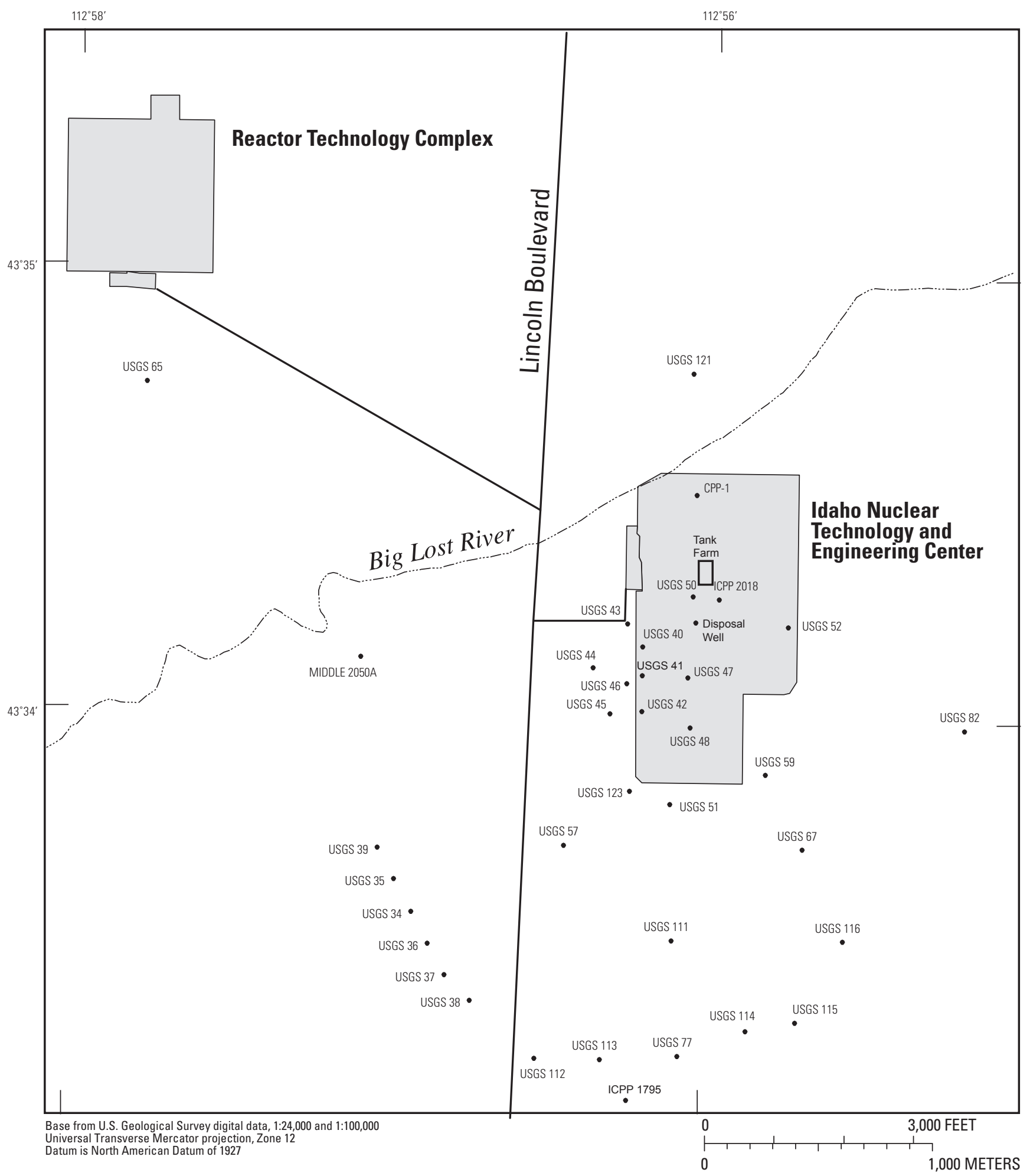

Figure 3. Location of wells near the Idaho Nuclear Technology and Engineering Center, Idaho National Laboratory, Idaho. 
At the INL, depth to water in wells completed in the ESRP aquifer ranges from about $200 \mathrm{ft}$ in the northern part of the site to more than $900 \mathrm{ft}$ in its southeastern part. A significant proportion of the ground water moves through the upper 200-800 ft of basaltic rocks (Mann, 1986, p. 21). Ackerman (1991, p. 30) and Bartholomay and others (1997, table 3) reported a range of transmissivity of basalt in the upper part of the aquifer of 1.1 to $760,000 \mathrm{ft}^{2} / \mathrm{d}$. The hydraulic gradient at the INL ranges from 2 to $10 \mathrm{ft} / \mathrm{mi}$, with an average of about $4 \mathrm{ft} / \mathrm{mi}$ (Davis, 2006, figure 9). Horizontal flow velocities of 2 to $20 \mathrm{ft} / \mathrm{d}$ have been calculated based on the movement of various constituents in several areas of the aquifer at the INL (Robertson and others, 1974; Mann and Beasley, 1994b; Cecil and others, 2000; Busenberg and others, 2001). These flow rates equate to a travel time of about 70-700 years for water beneath the INL to travel to springs that discharge at the terminus of the ESRP aquifer. Localized tracer tests at the INL have shown vertical and horizontal transport rates as high as $60-150 \mathrm{ft} / \mathrm{day}$ (Nimmo and others, 2002; Duke and others, 2007).

\section{Previous Investigations}

Many investigations have been done to evaluate the geology and hydrology of the ESRP aquifer at the INL. A comprehensive listing of publications by the USGS is available at http://id.water.usgs.gov/projects/INL/publication. $\underline{\mathrm{html}}$.

Previous investigations of ${ }^{129} \mathrm{I}$ in water from the ESRP aquifer include those by Barraclough and others (1982), Lewis and Jensen (1985), Mann and others (1988), Mann and Beasley (1994a; 1994b), Cecil and others (2003), U.S. Department of Energy (2004, 2007, 2008), Hall (2006), and Forbes and others (2007). Results from April 1977 sampling for ${ }^{129} \mathrm{I}$ in 14 wells indicated concentrations ranged from 0.9 to $27 \mathrm{pCi} / \mathrm{L}$ for statistically positive values (Barraclough and others, 1982, fig. 42), and since discharge began in 1953, ${ }^{129} \mathrm{I}$ was identified in wells less than $3 \mathrm{mi}$ from the disposal well. In October 1981, concentrations of ${ }^{129}$ I ranged from 0.05 to $41 \mathrm{pCi} / \mathrm{L}$ for statistically positive values (Lewis and Jensen, 1985), and since discharge began in 1953, ${ }^{129} \mathrm{I}$ was identified in wells about $6.3 \mathrm{mi}$ from the disposal well. The major difference between the 1977 and 1981 results was that the sample size was increased from 1 to $4 \mathrm{~L}$ for a four-fold reduction in the reporting level. The increase in sensitivity of analyses (Lewis and Jensen, 1985), along with a more extensive set of wells sampled (20 in 1977 and 32 in 1981) were the primary reasons for the increase in the size of the ${ }^{129} \mathrm{I}$ plume. In August 1986, ${ }^{129} \mathrm{I}$ concentrations ranged from $0.49 \pm 0.12$ to $3.6 \pm 0.4 \mathrm{pCi} / \mathrm{L}$ for 20 wells, with concentrations greater than the reporting level (Mann and others, 1988), and ${ }^{129} \mathrm{I}$ had migrated about the same distance from the disposal well as in 1981. The large decrease in the maximum concentration between 1981 and 1986 was attributed to changes in disposal practices at the INTEC, reduction in the mass of ${ }^{129} \mathrm{I}$ in wastewater, and to increased dilution in the mid-1980s from a large amount of flow in the Big Lost River (Mann and others, 1988).

Prior to the 1990-91 data collection, neutron activation methods were used for analyses. During 1990-91, Mann and Beasley (1994b) collected samples from 51 wells at and near the INL, and they analyzed the samples using an accelerator mass spectrometer (AMS) method. The AMS method allowed for increased sensitivity of the analyses (2 to 6 times more sensitive than neutron activation). The increased sensitivity allowed for determining a background concentration of $0.0000009 \pm 0.0000002 \mathrm{pCi} / \mathrm{L}$ from a sample located upgradiant from the INTEC. The increased sensitivity resulted in detectable concentrations of ${ }^{129} \mathrm{I}$ downgradient of the INL that were used to calculate ground-water flow velocities of at least $6 \mathrm{ft} / \mathrm{d}$. The maximum concentration detected in 1990-91 samples was $3.82 \pm 0.19 \mathrm{pCi} / \mathrm{L}$, which was similar to the maximum concentration detected in 1986; however, mean concentrations from 18 wells sampled in 1986 and 1990-91 decreased from $1.30 \pm 0.26$ to $0.81 \pm 0.19 \mathrm{pCi} / \mathrm{L}$ (Mann and Beasley, 1994b). This decrease was attributed largely to a decrease in disposal rates.

In 1992, Mann and Beasley (1994a) collected ground water and surface water samples from 16 sites not likely to have been affected by wastewater disposal at the INTEC to determine background concentrations of ${ }^{129} \mathrm{I}$. Concentrations of ${ }^{129} \mathrm{I}$ in water from nine wells, four springs, and three streams on or tributary to the ESRP ranged from 0.0000001 \pm 0.0000001 to $0.0000081 \pm 0.0000006 \mathrm{pCi} / \mathrm{L}$ (average of $0.0000033 \pm 0.0000021 \mathrm{pCi} / \mathrm{L}$ ). At the 99 -percent confidence level, background concentrations of ${ }^{129}$ I for the 16 sites were estimated to be less than or equal to $0.0000082 \mathrm{pCi} / \mathrm{L}$. Cecil and others (2003) reevaluated the background concentrations by analyzing results of 52 samples collected from ground water and surface water in 1992-94 from various locations in the ESRP in southeastern Idaho, and includes the samples collected by Mann and Beasley (1994a). Cecil and others (2003) determined that surface water samples generally contained larger ${ }^{129} \mathrm{I}$ concentrations than ground water samples because of anthropogenic fallout and evapotranspiration. They determined background concentrations using a subset of 30 water samples from wells analyzed to be $0.0000054 \mathrm{pCi} / \mathrm{L}$, and the 95-percent nonparametric confidence interval was 0.0000052 to $0.00001 \mathrm{pCi} / \mathrm{L}$.

Hall (2006) collected samples from 13 sites downgradient of the INL during 1997 and 1998. Using AMS methods, Hall (2006) determined that concentrations in four of the sites-USGS 11, 14, 124, and 125 [ig. 2])-were greater than 
estimated background concentrations, and he postulated that 1958 peak ${ }^{129} \mathrm{I}$ in the ESRP aquifer had already passed these wells. Concentrations of the four sites ranged from 0.0000061 \pm 0.00000018 to $0.00074 \pm 0.00003 \mathrm{pCi} / \mathrm{L}$, but they were less than concentrations measured in 1991 and 1993.

U.S. Department of Energy (2004) collected samples from four wells south of the INTEC (ICPP 1795-1798, figs. 2 and $\underline{3}$ ) from three zones in the aquifer to determine concentrations above and below the H-I interbed.

Concentrations of ${ }^{129} \mathrm{I}$ in well ICPP-1795 (northernmost well, fig. 3) increased from $0.34 \pm 0.04 \mathrm{pCi} / \mathrm{L}$ at $560 \mathrm{ft}$ below land surface to $0.43 \pm 0.07 \mathrm{pCi} / \mathrm{L}$ at $620 \mathrm{ft}$ below land surface. The three wells farther to the south showed a decrease in ${ }^{129}$ I concentration with depth, with concentrations in the upper zone ranging from $0.58 \pm 0.1$ to $0.88 \pm 0.08 \mathrm{pCi} / \mathrm{L}$ and concentrations in the lower zone ranging from not detected to $0.33 \pm 0.05 \mathrm{pCi} / \mathrm{L}$. The U.S. Department of Energy (2004, fig. 5-5) also presented results from analyses of 49 wells sampled in 2001; concentrations ranged from less than the method detection level of approximately $0.1-1.06 \mathrm{pCi} / \mathrm{L}$. Analyses were completed using gamma spectroscopy methods. Concentrations for 20 sites sampled in 2003 were all less than the MCL of $1 \mathrm{pCi} / \mathrm{L}$ (DOE/ID 2004, fig. 6-1).

Forbes and others (2007) presented results for 25 wells sampled in 2006 near the INTEC; concentrations ranged from less than the reporting level to $0.65 \pm 0.097 \mathrm{pCi} / \mathrm{L}$ in USGS 67. Analyses of data collected from 2004-06 at wells around the INTEC indicated no discernable change in the concentrations when the uncertainty of the data was taken into account.

U.S. Department of Energy (2007) presented results for ${ }^{129} \mathrm{I}$ data collected in 2005 and 2006 from 24 wells downgradient of the INTEC and the RTC (including several wells south of the INL), along with results from five zones each from two Westbay ${ }^{\mathrm{TM}}$ equipped wells (Middle 2050A and 2051). Samples were analyzed using the AMS method at the Purdue Rare Isotope Measurement (PRIME) laboratory, Purdue University, West Lafayette, Indiana, and some comparison was made to the 2003 USGS data presented in this report. Results were used to speculate on the source of ${ }^{129} \mathrm{I}$ in wells around the RWMC. Concentrations in most southern wells were greater than background concentrations.

U.S. Department of Energy (2008) presented results for ${ }^{129}$ I data collected in 2007 from six zones in one Westbay ${ }^{\mathrm{TM}}$ equipped well (USGS 132). Samples were analyzed using the AMS method at the PRIME laboratory in Indiana, and the results from the six zones ranged from $0.0004 \pm 0.000013$ to $0.002 \pm 0.00009 \mathrm{pCi} / \mathrm{L}$. Results for all six zones were more than two orders of magnitude less than the MCL.

\section{Methods and Quality Assurance}

\section{Sample Collection Methods}

Sample collection by the USGS at the INL generally followed guidelines established by the USGS and documented in the USGS National Field Manual (U.S. Geological Survey, variously dated), and in Bartholomay and others (2003). Water was collected from wells with dedicated submersible pumps and from six wells equipped with dedicated Westbay ${ }^{\mathrm{TM}}$ packer sampling systems. The Westbay ${ }^{\mathrm{TM}}$ packer sampling systems allow for isolation of particular zones within the upper 30-650 $\mathrm{ft}$ of the aquifer for sample collection. The other monitoring wells sampled for this study consist of open boreholes with variable completion depths in the upper $30-500 \mathrm{ft}$ of the aquifer. The water sampled from these open boreholes often is a mixture of old, regional ground water with young water that recharged in or near the INL (Busenberg and others, 2001).

Water from wells equipped with dedicated pumps was monitored during sampling for temperature, $\mathrm{pH}$, and specific conductance using methods described by Wood (1981) and Claassen (1982). Water samples in 2003 were collected after field measurements stabilized and after one volume of water was purged from each well. In 2007, water samples were collected after field measurements stabilized and after 1 volume of water was purged from each well. Samples collected prior to October 2003 were collected after 3 volumes of water were purged. Bartholomay (1993) and Knobel (2006) determined that the difference between purging 1 and 3 wellbore volumes at selected INL wells had no discernable effect on statistical comparability of select water-quality data.

For wells with dedicated Westbay ${ }^{\mathrm{TM}}$ packer sampling systems, pre-cleaned stainless-steel thief sampling bottles were lowered to the zone to be sampled, connected to the sampling port, and filled with formation water. The filled stainless-steel bottles then were raised to the surface and emptied into a pre-cleaned container; the water was then processed to fill 1-L glass amber bottles. Field measurements also were taken from the pre-cleaned container.

Field processing of all samples consisted of filtering the water through a disposable 0.45 -micrometer filter cartridge that had been pre-rinsed with at least $1 \mathrm{~L}$ of deionized water or $1 \mathrm{~L}$ of sample water. Filtration was necessary to remove particulate matter that could affect the laboratory preparation of the silver-iodide targets used in the AMS measurements of ${ }^{129} \mathrm{I}$ (Cecil and others, 2003). 


\section{Analytical Methods}

Iodine-129 concentrations in the ground water samples were determined using AMS methods described by Sharma and others (1997) and quality assurance requirements described by Mark Caffee, Purdue University (written commun., accessed February 12, 2008, at https://www.physics. purdue.edu/ams/AMSQAQC/normaq.php). The AMS used to analyze the samples is located at the PRIME laboratory, Purdue University, West Lafayette, Indiana. Water samples go through a chemical process to produce a silver iodide target material. The silver iodide is prepared after the addition of an iodine carrier, and the target is placed in a holder for AMS analyses. Analyses of the target produce a ratio of ${ }^{129} \mathrm{I}$ to stable iodine-127 ( $\left.{ }^{127} \mathrm{I}\right)$.

\section{Guidelines for Interpretation of Analytical Results}

Concentrations of ${ }^{129} \mathrm{I}$ are reported with an estimated sample standard deviation, $\mathrm{s}$, which is obtained by propagating sources of analytical uncertainty in measurements. The guidelines for interpreting analytical results are based on an extension of a method proposed by Currie (1984) and are given in Mann and Beasley (1994b). In this report, ${ }^{129}$ I concentrations less than $3 \mathrm{~s}$ are considered less than a "reporting level." The reporting level should not be confused with the analytical method detection limit, which is based on laboratory procedures.

Laboratory results from 2003 analyses were reported by the PRIME laboratory as the ratio of ${ }^{129} \mathrm{I}$ to ${ }^{127} \mathrm{I}$ and converted to concentrations in picocuries per liter $(\mathrm{pCi} / \mathrm{L})$ by using an equation described by Rao (1997):

$$
S_{T}=\frac{\left[R_{m}\left(C_{c} C_{v}+S_{c} S_{v}\right)-C_{c} C_{v} C_{r}\right] N}{f S_{v}}
$$

where

$S_{T}$ is the ${ }^{129}$ I concentration in atoms per liter of water,

$R_{m}$ is the ratio of ${ }^{129} \mathrm{I} /{ }^{127}$ I measured by AMS,

$C_{c}$ is the concentration of iodine in grams per liter $(\mathrm{g} / \mathrm{L})$ of carrier solution,

$C_{v}$ is the volume of carrier solution added in $\mathrm{L}$, $C_{r}$ is ${ }^{129} \mathrm{I} /{ }^{127} \mathrm{I}$ ratio for carrier solution,

$S_{c}$ is the concentration of iodine in $\mathrm{g} / \mathrm{L}$ for sample,

$S_{v}$ is the volume of the sample in $\mathrm{L}$,

$N$ is Avogadro's number $\left(6.023 \times 10^{23}\right.$ atoms $/$ mole $)$, and

$f$ is the formula weight for iodine (126.9 grams per mole).
The mass of the carrier given by the PRIME laboratory is the product of carrier volume $\left(C_{v}\right)$ and carrier concentration $\left(C_{C}\right)$ in milligrams. The concentration of iodine in most samples was less than $0.002 \mathrm{mg} / \mathrm{L}$, which was used for the concentration for all samples except those with estimated or reported concentrations.

In 2007, the laboratory reported results in ratios of ${ }^{129} \mathrm{I} / 127 \mathrm{I}$ and in $\mathrm{pCi} / \mathrm{L}$ based on the equation:

$\frac{p C i}{L}($ sample $)=\frac{\left(R_{s}-R_{b}\right) \times\left(W_{s}+W_{c}\right) \times 1.80 \times 10^{-7}}{W t}\left(\frac{p C i}{\mathrm{~L}}\right)$,

where

$R_{S}$ is the measured sample ratio of ${ }^{129} \mathrm{I}$ atoms to

${ }^{127} \mathrm{I}$ atoms,

$R_{b}$ is the ratio of the chemistry blank,

$W_{s}$ is the weight of ${ }^{127} \mathrm{I}$ in sample (in $\mathrm{mg}$ ),

$W_{c}$ is the weight of ${ }^{127}$ I added as carrier (in $\mathrm{mg}$ ), and

$W t$ is weight of sample (aliquot).

The laboratory calculations do not take into account the concentration of iodine in the sample because the concentration typically is negligible; the concentrations were estimated in the equation (Rao, 1997) used for the 2003 data. Differences between the reported concentrations are similar between both equations when sample ratios are larger than carrier blank ratios; however, when ${ }^{129} \mathrm{I} /{ }^{127} \mathrm{I}$ ratios of the samples are less than the ratio for the carrier blank sample, negative results occur for calculations based on the Rao (1997) equation. The PRIME lab did not subtract the carrier blank ratios for the samples that had carrier blank ratios larger than sample ratios (Susan Ma, PRIME lab, written commun., September 7, 2008). This difference in calculation methods between 2003 and 2007 results does not affect the comparability of the data between these analysis periods.

\section{Quality Assurance/Quality Control}

Quality assurance and reproducibility were assessed with QA/QC replicate and blank samples submitted for AMS analysis along with the standard samples. Four QA/ QC replicate samples were collected in 2003; three QA/ $\mathrm{QC}$ replicates and three QA/QC field blanks were collected in 2007. The blanks consisted of inorganic-free water obtained from the USGS National Water Quality Laboratory that was passed through the field equipment used for sample collection. Results for two of the blanks were near (QAI-4, 0.000071 $\pm 0.000015 \mathrm{pCi} / \mathrm{L}$ ) or below background concentrations (QAI-6, $0.0000014 \pm 0.0000002 \mathrm{pCi} / \mathrm{L}$ ). 
The third blank sample (QAI-1, table 1) had a concentration of $0.0025 \pm 0.0005 \mathrm{pCi} / \mathrm{L}$. This sample was from the same batch of inorganic free water as QAI-6. The blanks (QAI-1 and QAI-6) were processed in the field during different times of year. Samples QAI-1 and QAI-4 were processed as unknowns with estimated concentrations of $1 \mathrm{pCi} / \mathrm{L}$, so PRIME used a large dilution factor during processing. QAI-6 was processed as a blank with a concentration less than background, so no dilution in the chemical process was used. A rerun for QAI-4 (table 2) was done with no dilution, and the concentration $(0.000001 \pm 0.00000005 \mathrm{pCi} / \mathrm{L})$ was less than background. The laboratory discarded the QAI-1 sample before a rerun was requested, so the sample could not be rerun without dilution. The difference between the analytical results was not resolved.

Statistical equivalency of radiochemical-constituent concentrations in sample replicate pairs was determined following a method defined by Volk (1969) and described in more detail by Williams (1996). In this method, statistical equivalence is determined within a specified confidence level. A value for the standard deviate, $Z$, is calculated, and then the level of significance of the result is evaluated (evaluation of the level of significance assumes that the sample population is distributed normally). For this report, concentrations of individual constituents in sample pairs (constituent pairs) were considered equivalent when the results were within 2 standard deviations of each other. At this confidence level (95-percent), the level of significance, determined from a standard normal probability curve, was 0.05 for a two-tailed test, and it corresponded to a $Z$-value of 1.96 .

The equation used to determine $Z$ was adapted from Volk (1969):

where

$$
Z=\frac{|x-y|}{\sqrt{\left(s_{x}\right)^{2}+\left(s_{y}\right)^{2}}},
$$

\footnotetext{
$x$ is the concentration of a constituent in the routine sample,

$y$ is the concentration of the same constituent in the sequential replicate sample,

$s_{x}$ is the standard deviation of $x$, and

$s_{y}$ is the standard deviation of $y$.
}

When the population is not distributed normally, which often is the case with radiochemical results (L. DeWayne Cecil, U.S. Geological Survey, written commun., January 4, 2009), or an approximation of the standard deviation is used, a $Z$-value less than 1.96 must be considered as a guide when testing for equivalence. Constituent concentrations in sample pairs were considered statistically equivalent when the calculated $Z$-value was less than or equal to 1.96 .

The use of equation 3 therefore is considered a guide in determining if the results of ${ }^{129} \mathrm{I}$ analyses of a replicate pair of samples were equivalent. The results and reported standard deviations for the analyses of ${ }^{129} \mathrm{I}$ replicate pairs and the $Z$-values are listed in tables 1 and 2 . Results for five of the seven replicate pairs had $Z$-values less than 1.96 and can be considered statistically equivalent.

Both samples with results not considered statistically equivalent using equation 3 had uncertainties several orders of magnitude smaller than the concentrations that caused them to have $Z$-values greater than 1.96. If the uncertainty of the result is not used, the relative percent difference (RPD) can be used to compare equivalency of replicate pairs. The RPD is calculated based on the formula:

$$
\mathrm{RPD}=((\mathrm{ABS}(\mathrm{X} 1-\mathrm{X} 2)) /((\mathrm{X} 1+\mathrm{X} 2) / 2)) * 100,
$$

where

RPD is relative percent difference,

ABS is absolute value,

$\mathrm{X} 1$ is result for primary environmental sample, and $\mathrm{X} 2$ is result for field replicate sample.

A typical data-quality objective for field replicate samples is a maximum relative percent difference of 20 percent (Taylor, 1987), and results for both pairs with $Z$-values greater than 1.96 had RPDs less than 20 percent (USGS 85 and replicate was 12 percent and USGS 106 and replicate was 16 percent) using equation 4 . Results of replicate and blank samples (other than the one blank mentioned previously) generally indicated that the sample collection and laboratory procedures used were appropriate for the data obtained. 
Table 1. Concentrations of iodine-129 in ground water, Idaho National Laboratory, Idaho, 2003 and 2007.

[Well locations are shown in figures 2 and $\underline{3}$. Concentrations and analytical uncertainties are in picocuries per liter; uncertainties are 1 standard deviation. Z-value: the statistical test used to compare replicate values. Abbreviations: pCi/L, picocurie per liter; NA, not applicable; NS, not sampled; USGS, U.S. Geological Survey; QA, quality assurance; QAI, quality assurance iodine]

\begin{tabular}{|c|c|c|c|c|c|c|}
\hline Well identifier & Date sampled & $\begin{array}{l}\text { lodine-129 } \\
2003 \text { (pCi/L) }\end{array}$ & Z-value & Date sampled & $\begin{array}{l}\text { lodine-129 } \\
2007 \text { (pCi/L) }\end{array}$ & Z-value \\
\hline CFA-1 & NA & NS & NA & 04-19-07 & $0.318 \pm 0.015$ & NA \\
\hline CPP-1 & NA & NS & NA & $04-11-07$ & $0.0237 \pm 0.0022$ & NA \\
\hline EBR-1 & NA & NS & NA & 04-19-07 & $0.0084 \pm 0.0014$ & NA \\
\hline Rifle Range & NA & NS & NA & $10-23-07$ & $0.001 \pm 0.004$ & NA \\
\hline RWMC Prod. & NA & NS & NA & $10-11-07$ & $0.0188 \pm 0.0005$ & NA \\
\hline USGS 9 & $10-09-03$ & $0.0000088 \pm 0.00000035$ & NA & NA & NS & NA \\
\hline USGS 11 & $10-08-03$ & $0.000018 \pm 0.0000005$ & NA & NA & NS & NA \\
\hline USGS 14 & $10-08-03$ & $0.00004 \pm 0.000002$ & NA & NA & NS & NA \\
\hline USGS 35 & $10-23-03$ & $0.0018 \pm 0.00002$ & NA & NA & NS & NA \\
\hline USGS 36 & $11-13-03$ & $0.162 \pm 0.008$ & 0.09 & NA & NS & NA \\
\hline QA 9/USGS 36 & $11-13-03$ & $0.164 \pm 0.007$ & NA & NA & NS & NA \\
\hline USGS 37 & $11-13-03$ & $0.452 \pm 0.025$ & NA & $10-16-07$ & $0.395 \pm 0.017$ & NA \\
\hline USGS 38 & $11-13-03$ & $0.556 \pm 0.019$ & NA & $04-16-07$ & $0.281 \pm 0.008$ & NA \\
\hline USGS 39 & $11-03-03$ & $0.00028 \pm 0.000003$ & NA & $10-15-07$ & $0.000532 \pm 0.000025$ & NA \\
\hline USGS 40 & NA & NS & NA & $04-11-07$ & $0.306 \pm 0.01$ & NA \\
\hline USGS 42 & $11-10-03$ & $0.216 \pm 0.0064$ & NA & $04-11-07$ & $0.325 \pm 0.01$ & NA \\
\hline USGS 44 & $11-10-03$ & $0.12 \pm 0.0035$ & NA & NA & NS & NA \\
\hline USGS 47 & $11-17-03$ & $0.621 \pm 0.022$ & NA & NA & NS & NA \\
\hline USGS 48 & NA & NS & NA & $10-31-07$ & $0.35 \pm 0.013$ & NA \\
\hline USGS 67 & NA & NS & NA & $10-15-07$ & $1.16 \pm 0.04$ & NA \\
\hline USGS 77 & $11-03-03$ & $0.586 \pm 0.0193$ & NA & $10-18-07$ & $0.71 \pm 0.04$ & NA \\
\hline USGS 82 & $11-06-03$ & $0.0112 \pm 0.0004$ & NA & 04-04-07 & $0.011 \pm 0.0004$ & NA \\
\hline USGS 85 & $11-04-03$ & $0.283 \pm 0.009$ & 2.31 & 04-10-07 & $0.173 \pm 0.006$ & NA \\
\hline QA 8/USGS 85 & $11-04-03$ & $0.251 \pm 0.0105$ & NA & NA & NS & NA \\
\hline USGS 88 & NA & NS & NA & $10-16-07$ & $0.000026 \pm 0.0000022$ & NA \\
\hline USGS 103 & $10-06-03$ & $0.00001 \pm 0.0000008$ & NA & NA & NS & NA \\
\hline USGS 103 & $10-06-03$ & $0.000009 \pm 0.0000003$ & NA & NA & NS & NA \\
\hline USGS 104 & $10-06-03$ & $0.0049 \pm 0.0002$ & NA & $10-24-07$ & $0.005 \pm 0.00023$ & NA \\
\hline USGS 105 & $10-02-03$ & $0.0017 \pm 0.0001$ & NA & $10-16-07$ & $0.00227 \pm 0.00009$ & NA \\
\hline USGS 106 & $10-02-03$ & $0.034 \pm 0.001$ & NA & $10-16-07$ & $0.0274 \pm 0.0013$ & 2.82 \\
\hline QAI-5/USGS 106 & NA & NS & NA & $10-16-07$ & $0.0322 \pm 0.0011$ & NA \\
\hline USGS 108 & $10-06-03$ & $0.0015 \pm 0.00005$ & NA & $04-24-07$ & $0.00102 \pm 0.00004$ & NA \\
\hline USGS 109 & $10-02-03$ & $0.0004 \pm 0.00001$ & NA & $04-17-07$ & $0.000677 \pm 0.00002$ & NA \\
\hline USGS 111 & $11-05-03$ & $0.138 \pm 0.007$ & NA & $04-11-07$ & $0.192 \pm 0.007$ & NA \\
\hline USGS 112 & $11-04-03$ & $0.617 \pm 0.067$ & 1.07 & NA & NS & NA \\
\hline
\end{tabular}


Table 1. Concentrations of iodine-129 in ground water, Idaho National Laboratory, Idaho, 2003 and 2007.-Continued

[Well locations are shown in figures 2 and $\underline{3}$. Concentrations and analytical uncertainties are in picocuries per liter; uncertainties are 1 standard deviation. Z-value: the statistical test used to compare replicate values. Abbreviations: pCi/L, picocurie per liter; NA, not applicable; NS, not sampled; USGS, U.S. Geological Survey; QA, quality assurance; QAI, quality assurance iodine]

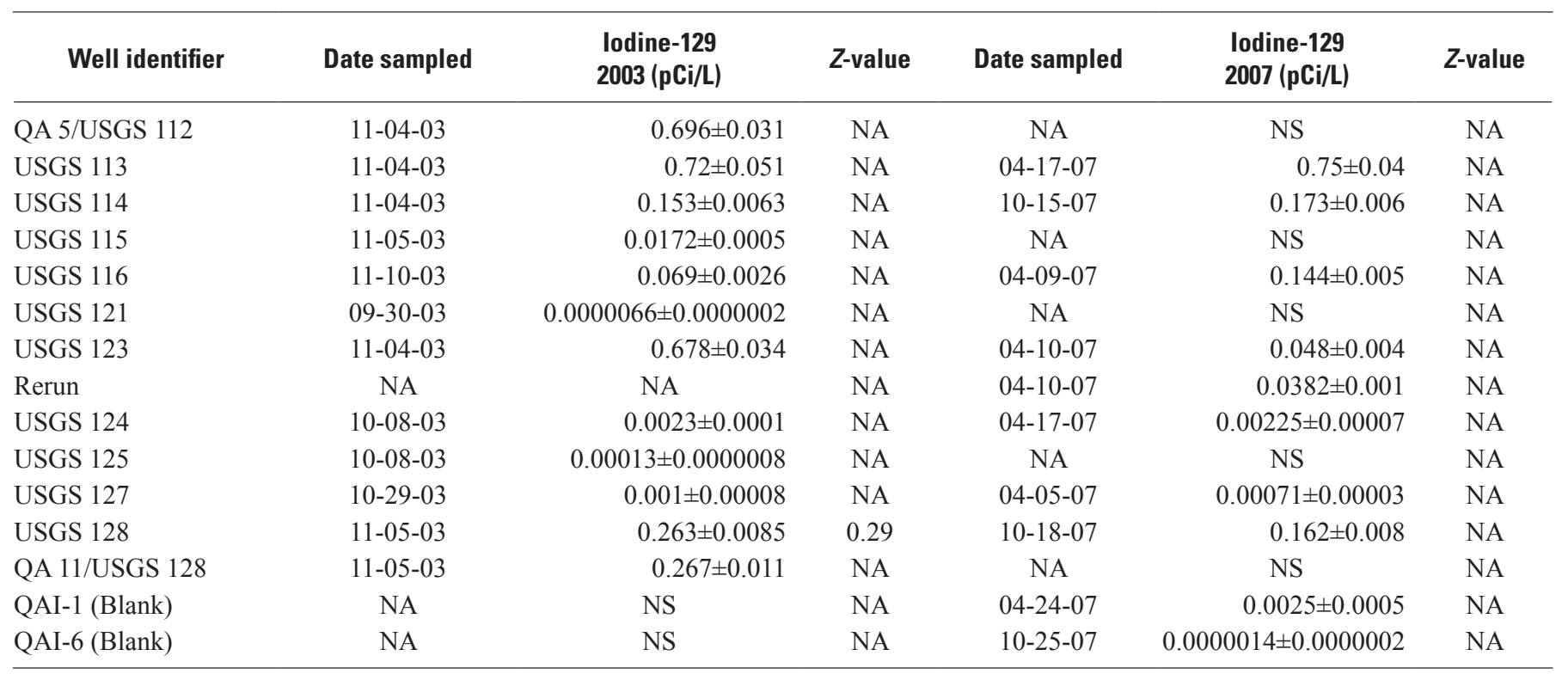

Table 2. Concentrations of iodine-129 at multiple aquifer depths, Idaho National Laboratory, Idaho, 2007.

[Well locations are shown in figures 2 and $\underline{3}$. Concentrations and analytical uncertainties are in picocuries per liter $(\mathrm{pCi} / \mathrm{L})$; uncertainties are $1 \mathrm{standard}$ deviation. Port depth: feet below land surface. Z-value: statistical test used to compare the replicate sample. QAI-3 is a replicate of Middle 2051 Zone 2. QAI-4 is an equipment blank of inorganic free water. Abbreviations: USGS, U.S. Geological Survey; NA, not applicable; NS, not sampled; QAI, quality assurance iodine]

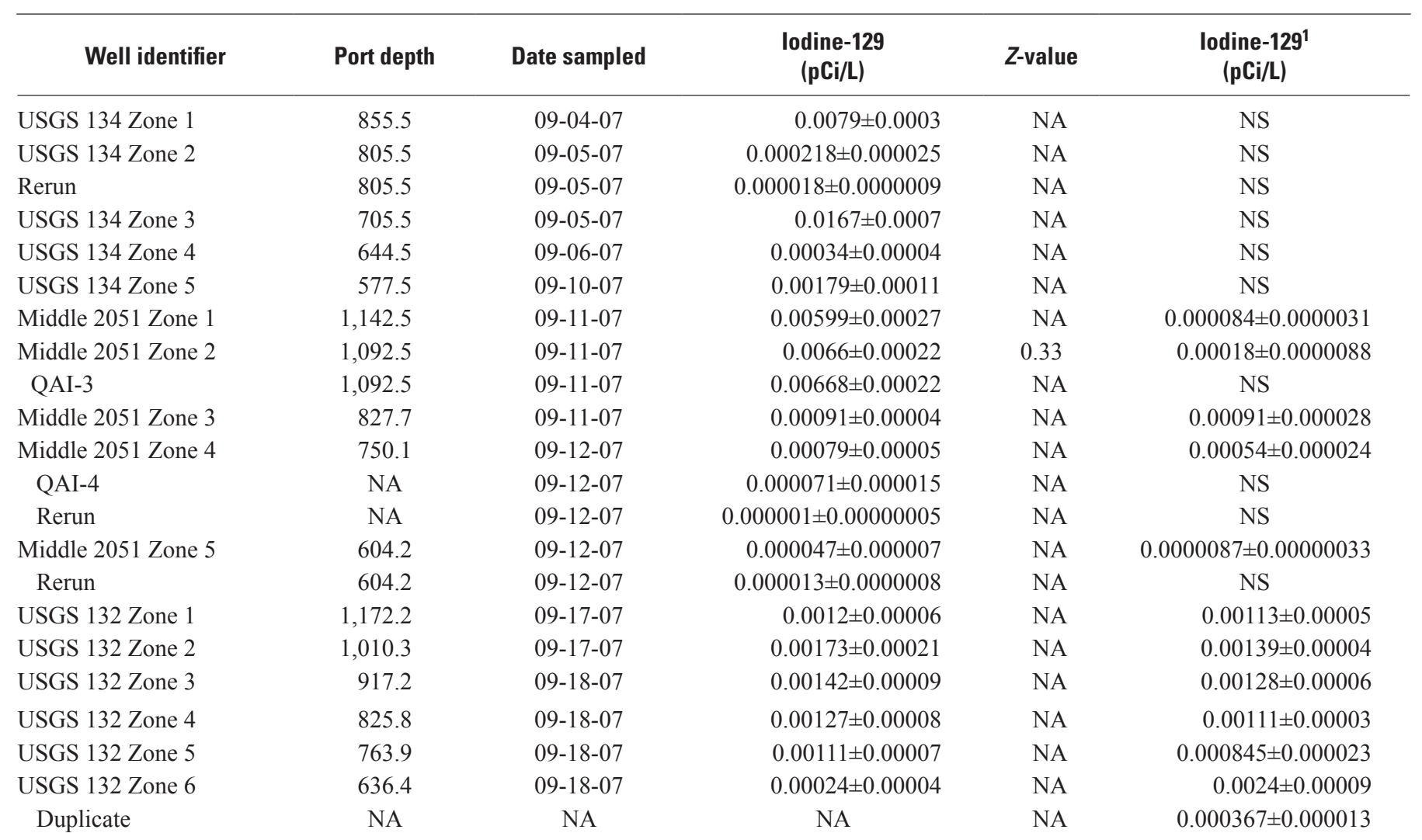


Table 2. Concentrations of iodine-129 at multiple aquifer depths, Idaho National Laboratory, Idaho, 2007.—Continued

[Well locations are shown in figures 2 and $\underline{3}$. Concentrations and analytical uncertainties are in picocuries per liter (pCi/L); uncertainties are 1 standard deviation. Port depth: feet below land surface. Z-value: statistical test used to compare the replicate sample. QAI-3 is a replicate of Middle 2051 Zone 2. QAI-4 is an equipment blank of inorganic free water. Abbreviations: USGS, U.S. Geological Survey; NA, not applicable; NS, not sampled; QAI, quality assurance iodine]

\begin{tabular}{|c|c|c|c|c|c|}
\hline Well identifier & Port depth & Date sampled & $\begin{array}{l}\text { lodine-129 } \\
\text { (pCi/L) }\end{array}$ & Z-value & $\begin{array}{l}\text { lodine-1291 } \\
(\mathrm{pCi} / \mathrm{L})\end{array}$ \\
\hline Middle 2050A Zone 1 & $1,178.8$ & 09-19-07 & $0.00027 \pm 0.00003$ & NA & $0.000046 \pm 0.0000017$ \\
\hline Middle 2050A Zone 3 & 790.2 & 09-20-07 & $0.0002 \pm 0.00003$ & NA & $0.000017 \pm 0.00000075$ \\
\hline Middle 2050A Zone 4 & 641.9 & 09-20-07 & $0.00019 \pm 0.00003$ & NA & $0.000018 \pm 0.00000063$ \\
\hline Middle 2050A Zone 5 & 514.9 & 09-20-07 & $0.00019 \pm 0.00005$ & NA & $0.000018 \pm 0.00000076$ \\
\hline Rerun & 744.3 & 09-24-07 & $0.000017 \pm 0.0000008$ & NA & NS \\
\hline USGS 133 Zone 2 & 684.9 & 09-24-07 & $0.00025 \pm 0.00004$ & NA & NS \\
\hline Rerun & 684.9 & 09-24-07 & $0.00005 \pm 0.0000025$ & NA & NS \\
\hline USGS 133 Zone 3 & 568.5 & 09-24-07 & $0.000186 \pm 0.000029$ & NA & NS \\
\hline Rerun & 568.5 & 09-24-07 & $0.000011 \pm 0.0000005$ & NA & NS \\
\hline USGS 103 Zone 3 & $1,095.1$ & $10-01-07$ & $0.0017 \pm 0.0014$ & NA & NS \\
\hline USGS 103 Zone 5 & 913.8 & $10-01-07$ & $0.00079 \pm 0.00003$ & NA & NS \\
\hline USGS 103 Zone 6 & 805.2 & $10-02-07$ & $0.000415 \pm 0.000018$ & NA & NS \\
\hline USGS 103 Zone 7 & 681.9 & $10-02-07$ & $0.0015 \pm 0.0001$ & NA & NS \\
\hline
\end{tabular}

${ }^{1}$ Data from U.S. Department of Energy, 2007, 2008.

\section{Concentrations of lodine-129 in the Snake River Plain Aquifer}

\section{Concentrations of lodine-129 in 2003}

In October 2003, water samples were collected from 36 wells that obtain water from the ESRP aquifer at or south of the INL. Additionally, water was collected from one well at the INTEC that obtains water from a perched ground-water zone that may eventually recharge to the ESRP aquifer. The areal distribution of concentrations greater than $0.1 \mathrm{pCi} / \mathrm{L}$ is shown in figure 4. Concentrations of ${ }^{129} \mathrm{I}$ in the aquifer ranged from $0.0000066 \pm 0.0000002$ to $0.72 \pm 0.051 \mathrm{pCi} / \mathrm{L}$, and the concentration of water from the perched zone at the INTEC was $0.669 \pm 0.023 \mathrm{pCi} / \mathrm{L}$ (table 1, fig. 4). Water from one aquifer well (USGS 121) had a concentration $(0.0000066 \mathrm{pCi} / \mathrm{L})$ that was within the uncertainty of the estimated background concentration of $0.0000054 \mathrm{pCi} / \mathrm{L}$ for the ESRP aquifer as calculated by Cecil and others (2003).
Well USGS 121, upgradient of the INTEC, was considered by Mann and Beasley (1994b) as a background well for comparative purposes.

Concentrations of ${ }^{129}$ I concentrations in the ESRP aquifer generally decreased from 1990-91 to 2003 (table 3). The average concentration of 19 wells sampled during both sample periods decreased from $0.975 \mathrm{pCi} / \mathrm{L}$ in $1990-91$ to $0.249 \mathrm{pCi} / \mathrm{L}$ in 2003 . Many of the wells within a 3 -mi radius of the INTEC showed decreases of as much as one order of magnitude in concentration (table 3). These decreases are attributed to discontinuation of disposal of ${ }^{129} \mathrm{I}$ in wastewater after 1988 and to dilution and dispersion in the ESRP aquifer. Dilution from the Big Lost River probably was quite prevalent during 1995-2000 (Davis, 2006, fig. 8), and this additional dilution may have contributed to the marked decreases in the wells near the INTEC. The decrease in concentrations during 2003 is a continuance of the decreases described by Mann and Beasley (1994b) from earlier sampling periods. 


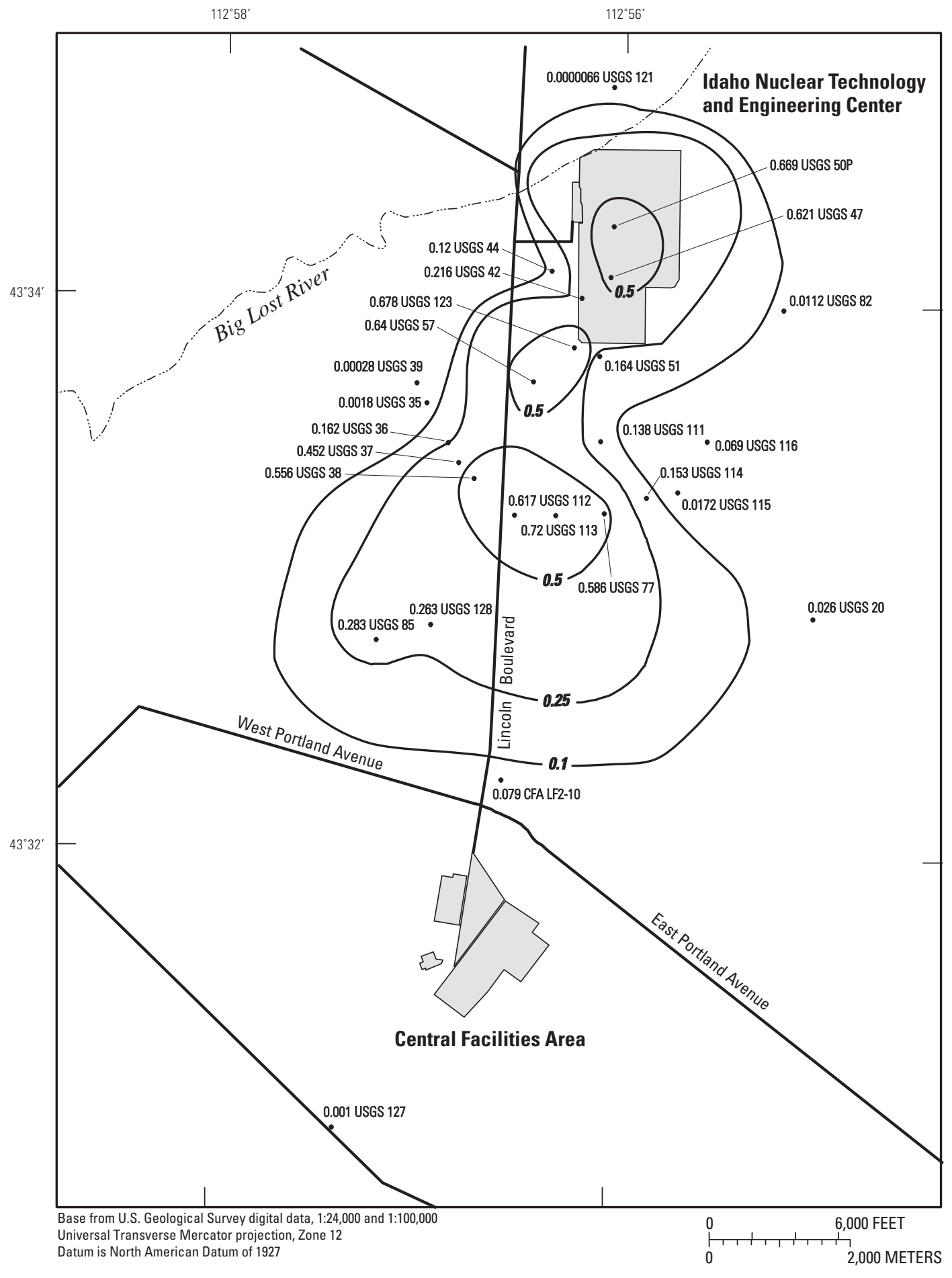

\section{EXPLANATION}

- $0.25-$ Line of Equal lodine-129 Concentration-Concentration in picocuries per liter. Lines of equal concentrations were interpreted from analyses of samples collected from a 3-dimensional flow system. Mapped concentrations represent samples collected from various depths in boreholes with differing well completions; for example, single and multiple screened intervals, and open boreholes. Location is approximate. Interval is variable.

0.669 USGS 50P - Well in the USGS Water-Quality Monitoring Network - Samples analyzed for iodine-129. 50P is local well identifier; $P$ indicates well obtains water from a perched qround-water zone.

Figure 4. Areal distribution of iodine-129 in the Snake River Plain aquifer at the Idaho National Laboratory, Idaho, 2003. 


\section{Iodine-129 in the Snake River Plain Aquifer at and Near the Idaho National Laboratory, Idaho, 2003 and 2007}

Table 3. Concentrations of iodine-129 in water from selected wells, Idaho National Laboratory, Idaho, 1990-91, 2003, and 2007.

[Well locations are shown in figures 2 and $\underline{3}$. Concentrations and analytical uncertainties are in picocuries per liter; uncertainties are 1 standard deviation. Average concentration calculated from the 19 wells with concentrations from all three sample periods (USGS 123 excluded because well was modified in 2004). Abbreviations: pCi/L, picocurie per liter; NS, not sampled; USGS, U.S. Geological Survey]

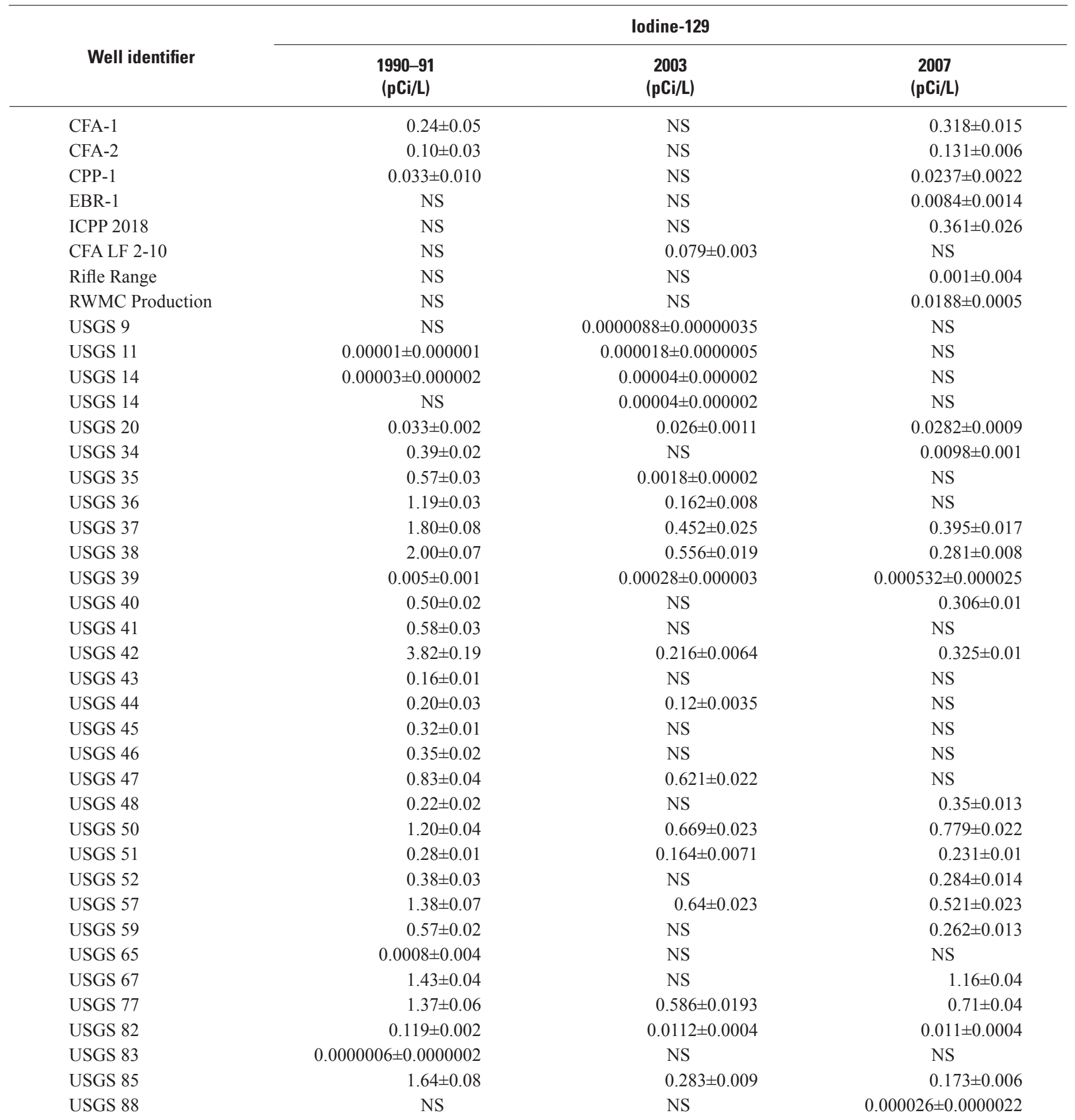


Table 3. Concentrations of iodine-129 in water from selected wells, Idaho National Laboratory, Idaho, 1990-91, 2003, and 2007.Continued

[Well locations are shown in figures 2 and $\underline{3}$. Concentrations and analytical uncertainties are in picocuries per liter; uncertainties are 1 standard deviation. Average concentration calculated from the 19 wells with concentrations from all three sample periods (USGS 123 excluded because well was modified in 2004 ). Abbreviations: pCi/L, picocurie per liter; NS, not sampled; USGS, U.S. Geological Survey]

\begin{tabular}{|c|c|c|c|}
\hline Well identifier & \multicolumn{3}{|c|}{ lodine-129 } \\
\hline USGS 103 & $0.00008 \pm 0.00005$ & $0.000009 \pm 0.0000003$ & NS \\
\hline USGS 104 & $0.0036 \pm 0.0001$ & $0.0049 \pm 0.0002$ & $0.005 \pm 0.00023$ \\
\hline USGS 108 & $0.00083 \pm 0.00002$ & $0.0015 \pm 0.00005$ & $0.00102 \pm 0.00004$ \\
\hline USGS 109 & NS & $0.0004 \pm 0.00001$ & $0.000677 \pm 0.00002$ \\
\hline USGS 111 & $0.86 \pm 0.09$ & $0.138 \pm 0.007$ & $0.192 \pm 0.007$ \\
\hline USGS 112 & $2.40 \pm 0.25$ & $0.617 \pm 0.067$ & NS \\
\hline USGS 113 & $3.25 \pm 0.14$ & $0.72 \pm 0.051$ & $0.75 \pm 0.04$ \\
\hline USGS 121 & $0.0000009 \pm 0.0000002$ & $0.0000066 \pm 0.0000002$ & NS \\
\hline USGS 123 & $1.00 \pm 0.05$ & $0.678 \pm 0.034$ & $0.048 \pm 0.004$ \\
\hline USGS 124 & NS & $0.0023 \pm 0.0001$ & $0.00225 \pm 0.00007$ \\
\hline USGS 125 & NS & $0.00013 \pm 0.0000008$ & NS \\
\hline USGS 127 & NS & $0.001 \pm 0.00008$ & $0.00071 \pm 0.00003$ \\
\hline USGS 128 & NS & $0.263 \pm 0.0085$ & $0.162 \pm 0.008$ \\
\hline Average concentration & 0.975 & 0.249 & 0.250 \\
\hline
\end{tabular}

Although the wells near the INTEC showed decreases of ${ }^{129} \mathrm{I}$, wells south and east of the Central Facilities Area (CFA) (USGS 104 and USGS 106), near the site boundary (USGS 105 and 108) and south of the INL (USGS 11 and 14) showed slight increases in concentrations between 1990-91 and 2003 (table 3, fig. 5). These slight increases may be related to variable discharge rates of wastewater that moved to these well locations as a mass of water from a particular disposal period. For example, the highest concentrations of ${ }^{129}$ I probably were in wastewater discharged in 1957 (U.S. Department of Energy 2004, appendix D) and 1978 (Mann and Beasley, 1994b, fig. 2; U.S. Department of Energy, 2004, appendix D). Therefore, when water reaches a well from discharge in 1957 and 1978, the concentration of the sample most likely would be greater than concentrations in samples of water discharged during other periods. Data from wells USGS 11 and USGS 14 from Hall (2006) somewhat support this idea because ${ }^{129} \mathrm{I}$ concentrations for these two wells were less in 1998 than during the 1990-91 and 2003 sample periods. Cecil and others (2000) indicated that 1958 peak disposal of chlorine-36 probably reached USGS 11 in 1984 and reached USGS 14 in 1987. Beasley and others (1998) examined the relative mobility of several isotopes disposed at the INTEC, and they concluded that chlorine-36 behaves conservatively in the basalt; however ${ }^{129} \mathrm{I}$ is attenuated, and probably moves more slowly in the system. Data for 1990-91 from some southern wells, therefore, could represent the end of high concentrations related to the large discharge event in 1957, and 2003 data could represent the beginning of high concentrations related to the 1978 discharge event or possibly some larger discharge event between 1957 and 1978. Accurately predicting the first arrival of peak concentrations with the limited sample periods and the complexity of the basaltic aquifer system is difficult because of the uncertainty of ${ }^{129} \mathrm{I}$ concentrations in wastewater discharged prior to 1976. 


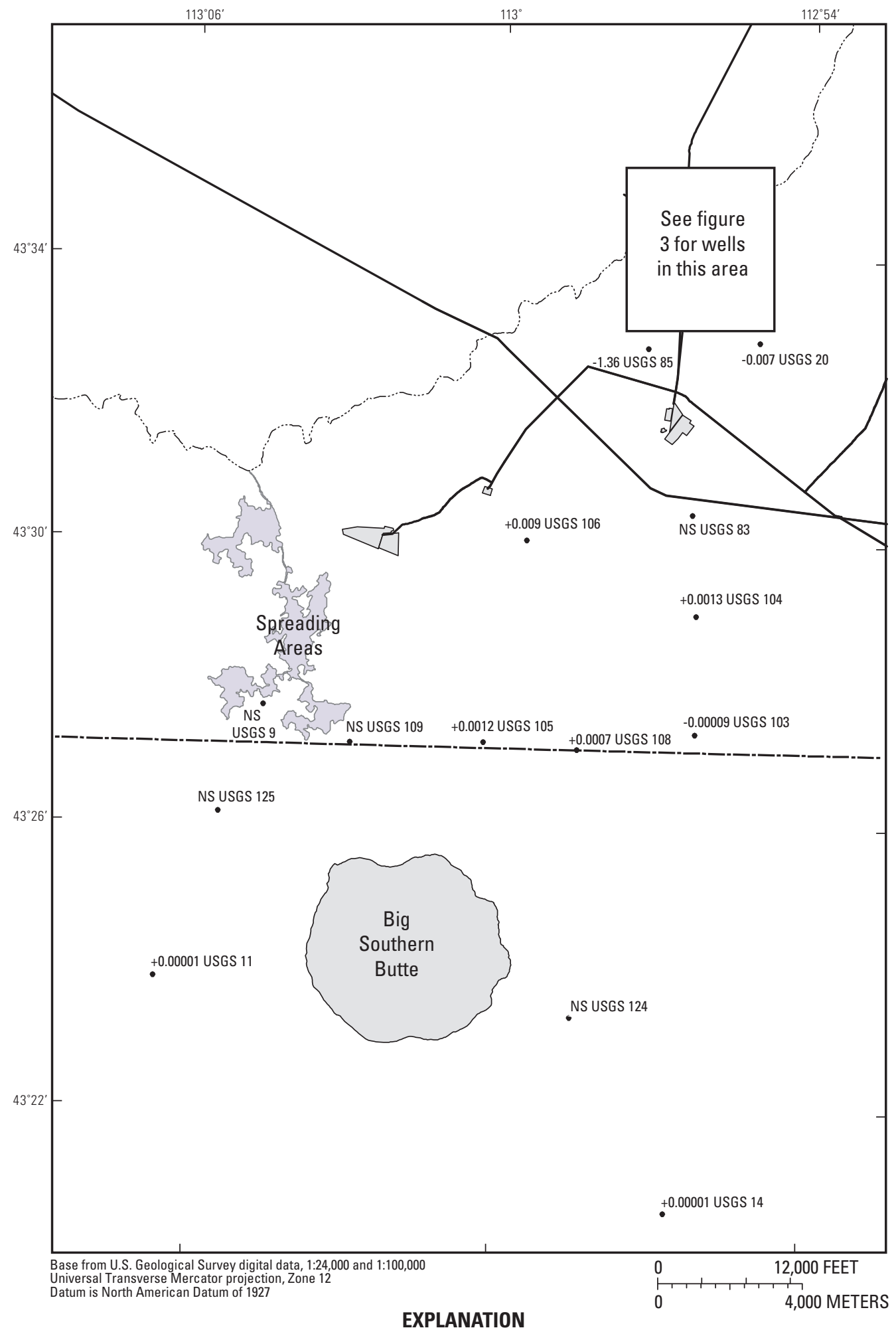

+0.0012 Change in lodine-129 Concentration Between 1991 and 2003-Concentration in picocuries per liter + indicates increase; - indicates decrease in concentration. NS, indicates no sample collected in both years. Data calculated from table 3. Location is approximate. Interval is variable.

USGS 105 Well in the USGS Water-Quality Monitoring Network-Samples analyzed for iodine-129.

Figure 5. Change in concentration of iodine-129 between samples collected from selected wells, Idaho National Laboratory, Idaho, 1990-91 and 2003. 


\section{Concentrations of lodine-129 in 2007}

During April and October 2007, water samples were collected from 36 wells that obtain water from the ESRP aquifer at or south of the INL. Additionally, water was collected from two wells at the INTEC that obtain water from a perched ground-water zone that may eventually recharge to the ESRP aquifer. The areal distribution of concentrations greater than $0.1 \mathrm{pCi} / \mathrm{L}$ is shown in figure 6 . Concentrations of ${ }^{129} \mathrm{I}$ in the ESRP aquifer ranged from $0.000026 \pm 0.000002$ to $1.16 \pm 0.04 \mathrm{pCi} / \mathrm{L}$, and the concentrations of water from the two perched zone wells (ICPP-2018 and USGS 50) at the INTEC were $0.361 \pm 0.026$ and $0.779 \pm 0.022 \mathrm{pCi} / \mathrm{L}$, respectively (table 1). Concentrations in water from all aquifer wells sampled were greater than the estimated background concentration of $0.0000054 \mathrm{pCi} / \mathrm{L}$ for the ESRP aquifer as calculated by Cecil and others (2003). One concentration in well USGS 67 exceeded the MCL of $1 \mathrm{pCi} / \mathrm{L}$ for public drinking water supplies, but the concentration was much less than the proposed MCL of $21 \mathrm{pCi} / \mathrm{L}$. Well USGS 67 was not sampled by the USGS for ${ }^{129}$ I in 2003 because of pump problems, but a concentration from this well was $0.68 \mathrm{pCi} / \mathrm{L}$ from a 2003 sample collected and analyzed by the site contractor using a different analytical method (U.S. Department of Energy, 2004, fig. 6-1).

On average, ${ }^{129} \mathrm{I}$ concentrations in the ESRP aquifer remained the same between 2003 and 2007 in 19 wells that were sampled during both years. The average concentration of ${ }^{129} \mathrm{I}$ in water from 19 wells sampled in 2003 was $0.249 \mathrm{pCi} / \mathrm{L}$; the average concentration of ${ }^{129} \mathrm{I}$ in water from the same wells sampled in 2007 was $0.250 \mathrm{pCi} / \mathrm{L}$ (table 3). These average concentrations were significantly less than the average concentration of $0.975 \mathrm{pCi} / \mathrm{L}$ for the same wells sampled in 1990-91. These decreases are attributed to the discontinuation of ${ }^{129}$ I disposal in wastewater after 1988 and to dilution and dispersion in the ESRP aquifer.

Although samples from several wells southwest of the INTEC showed slight decreases between 2003 and 2007 (USGS 37, 38, 57, and 123; table 3, fig. 7), samples from several other wells also showed some slight increases in concentration (USGS 42, 50, 51, 77, 111; table 3, fig. 7). With the exception of USGS 123, all samples from wells that showed the decrease in concentrations are west of the primary flow path from the INTEC. The sharp decrease of ${ }^{129} \mathrm{I}$ in water from USGS 123 probably can be attributed to the deepening of the well in 2004, which resulted in sampling a larger zone of the upper part of the aquifer, thereby probably diluting the sample (Forbes and others, 2007). Some recharge from the Big Lost River probably occurred because of surface water flow during 2005 and 2006 (Brennan and others, 2006; U.S. Geological Survey, 2006), accessed February 28, 2008,_at http://wdr.water.usgs.gov/) in the INTEC area. This additional recharge could have moved remnant perched water containing elevated ${ }^{129} \mathrm{I}$ concentrations from below the INTEC and (or) the infiltration ponds into the aquifer. An examination of sodium, chloride, and strontium-90 concentrations in the same wells that showed slight increases indicated similar slight increases in concentrations for some constituents between the 2003 and 2007 data; however, some decreases also are evident for some of the constituents (table 4). For example, USGS 42 showed a slight increase in all four constituents between samples collected in 2003 and 2007, and well USGS 77 showed an increase in sodium and ${ }^{129} \mathrm{I}$, but a decrease in chloride and strontium-90 (table 4). USGS 42 is upgradient of the infiltration ponds and is on the west side of the INTEC, so increases in concentrations probably are related to leakage around the facility reaching the aquifer. The high chloride concentration in USGS 77 in 2003 probably was related to remnant discharge of chloride in the infiltration ponds, and the decrease of the concentration in 2007 was attributed to the discontinued use of the infiltration ponds in 2002. The variability of constituent concentrations near the INTEC has been a continual issue because of the uncertainty of the amount of constituents that have leaked below ground at the facility and because of the uncertainty of the chemical exchange processes occurring in the unsaturated zone. 


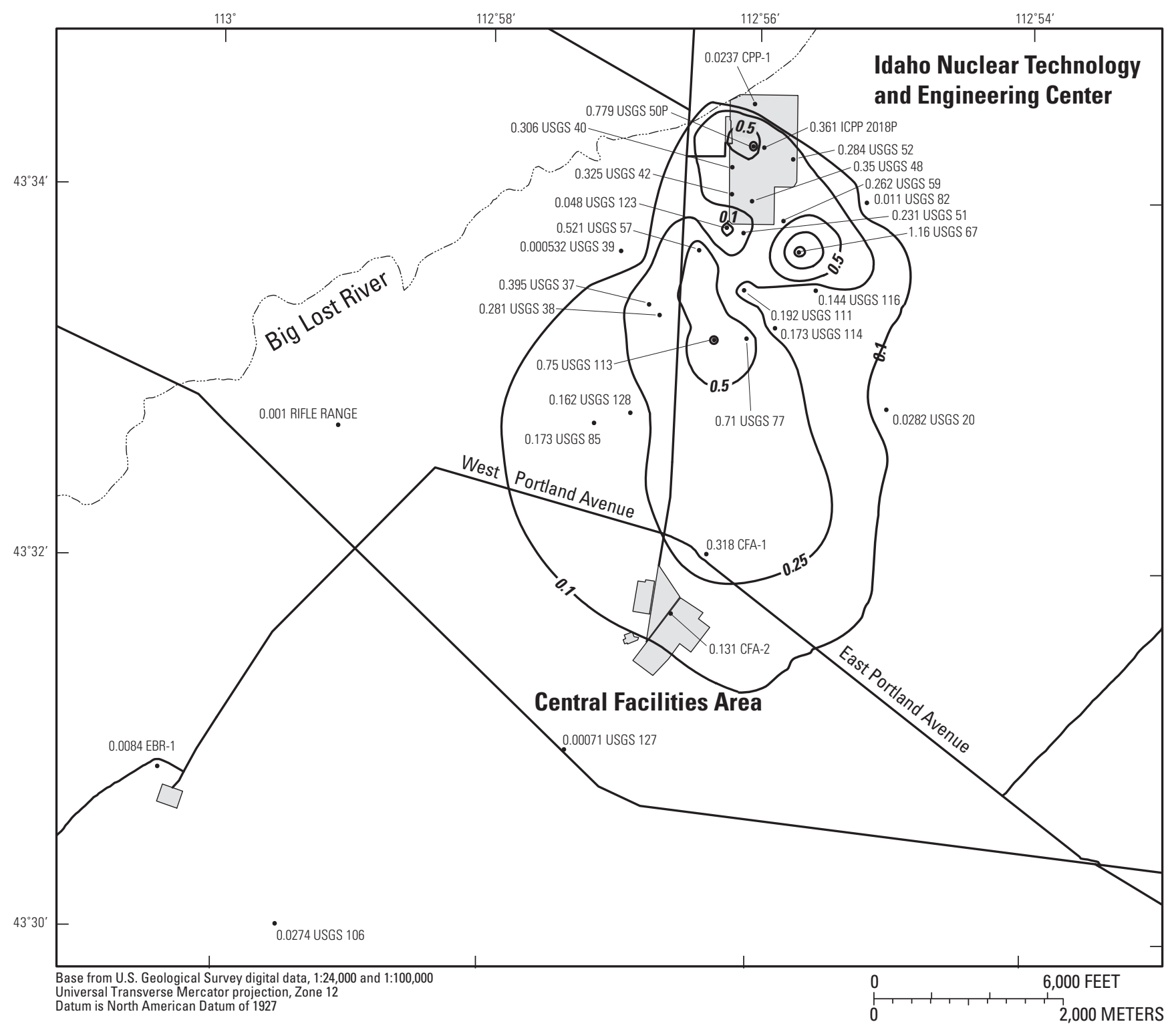

EXPLANATION

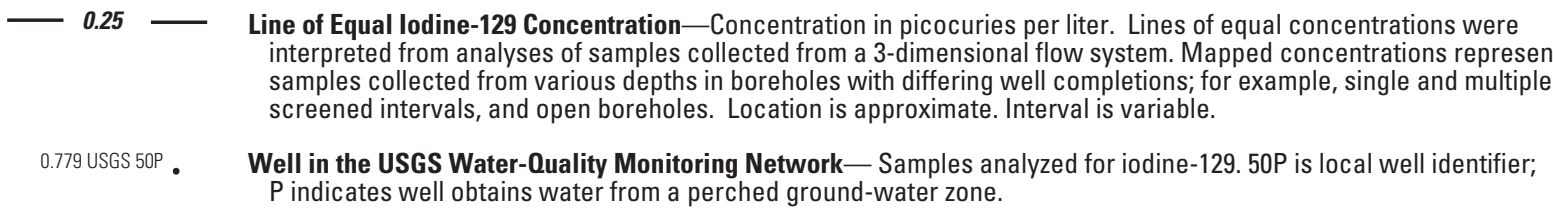

Figure 6. Areal distribution of iodine-129 in the Snake River Plain aquifer at the Idaho National Laboratory, Idaho, 2007. 


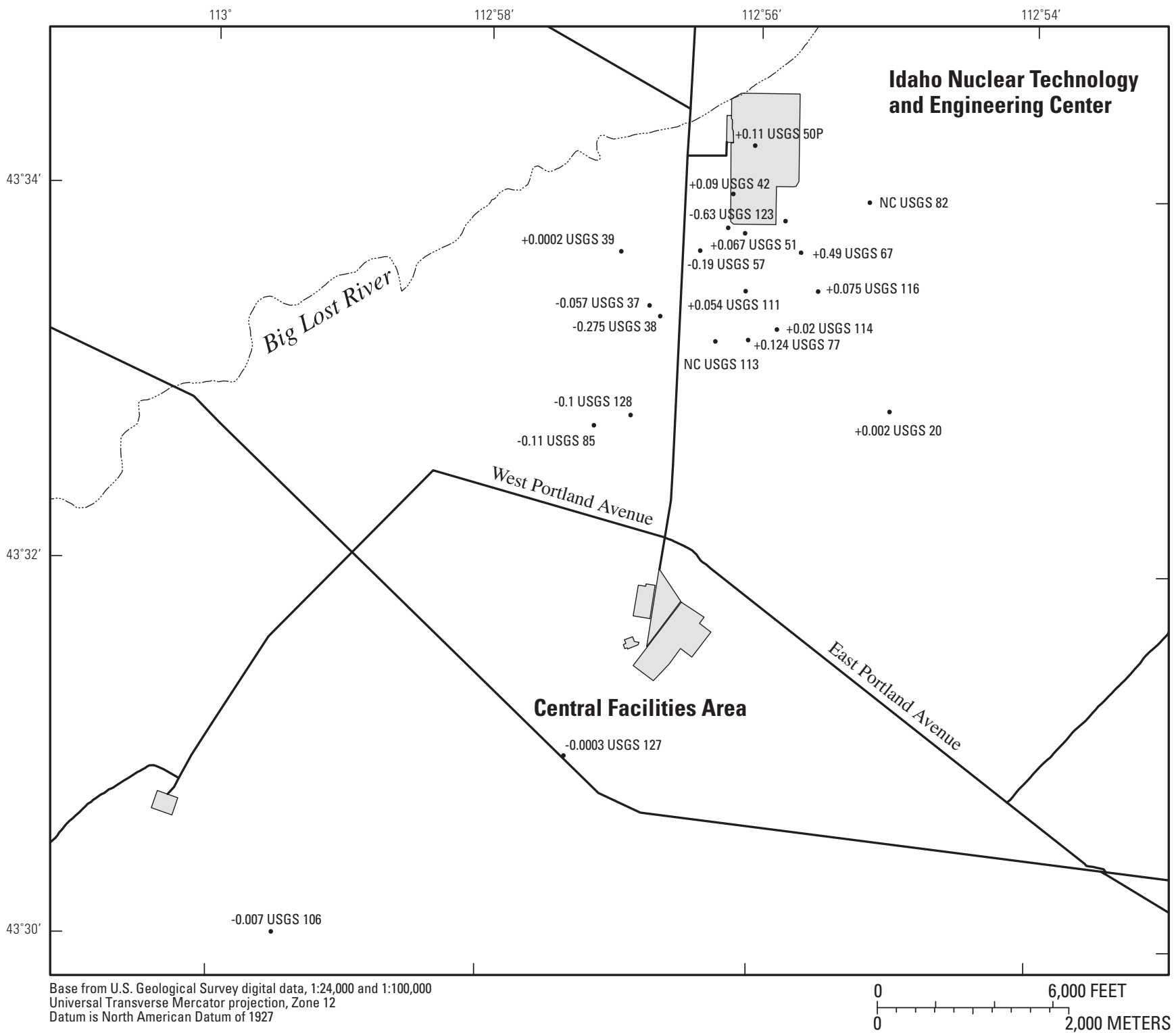

EXPLANATION

+0.49 Change in lodine-129 Concentration Between 2003 and 2007 -Concentration in picocuries per liter. + indicates increase; - indicates decrease in concentration. NC, indicates no statistically significant change between sample periods. Data calculated from table 3 except for USGS 67 which used data from U.S. Department of Energy (2004) for 2003 USGS 67 concentration. Location is approximate. Interval is variable.

+0.11 USGS 50P Well in the USGS Water-Quality Monitoring Network- Samples analyzed for iodine-129. USGS 50P is local well identifier; P indicates well obtains water from a perched ground-water zone.

Figure 7. Change in concentration of iodine-129 between water samples from wells at the Idaho National Laboratory, Idaho, 2003 and 2007. 
Table 4. Concentrations of chloride, iodine-129, sodium, and strontium-90 in water from selected wells, Idaho National Laboratory, Idaho, 2003 and 2007.

[Well locations are shown in figures 2 and $\underline{3}$. Concentrations of chloride and sodium are in milligrams per liter (mg/L). Concentrations and analytical uncertainties for iodine-129 and strontium-90 are in picocuries per liter $(\mathrm{pCi} / \mathrm{L})$. Uncertainties are 1 standard deviation. Data from 2003 are from October sampling unless noted. Abbreviation: NS, not sampled]

\begin{tabular}{|c|c|c|c|c|c|c|c|c|}
\hline $\begin{array}{c}\text { Well } \\
\text { identifier }\end{array}$ & \multicolumn{2}{|c|}{ Chloride } & \multicolumn{2}{|c|}{ lodine-129 } & \multicolumn{2}{|c|}{ Sodium } & \multicolumn{2}{|c|}{ Strontium-90 } \\
\hline USGS 38 & 45.3 & 16.9 & $0.556 \pm 0.019$ & $0.281 \pm 0.008$ & 27.8 & 13.8 & $13.1 \pm 0.8$ & $5.9 \pm 0.7$ \\
\hline USGS 42 & 18.2 & 18.8 & $0.216 \pm 0.0064$ & $0.325 \pm 0.01$ & 10.8 & 11.5 & $7.5 \pm 0.7$ & $9.7 \pm 0.8$ \\
\hline USGS 50 & 54.1 & 52.5 & $0.669 \pm 0.023$ & $0.779 \pm 0.022$ & 60 & 58.2 & $105 \pm 2$ & $101 \pm 2$ \\
\hline USGS 51 & 172 & 171 & $0.164 \pm 0.0071$ & $0.231 \pm 0.01$ & 34.7 & 36.3 & $0.6 \pm 0.5$ & $0.2 \pm 0.7$ \\
\hline USGS 57 & 60.3 & 24.6 & $0.64 \pm 0.023$ & $0.521 \pm 0.023$ & 30.4 & 15.3 & $18.5 \pm 0.9$ & $14 \pm 0.9$ \\
\hline USGS 67 & ${ }^{1} 160$ & 62.4 & NS & $1.16 \pm 0.04$ & NS & 30.9 & ${ }^{1} 9 \pm 0.7$ & $15.9 \pm 0.9$ \\
\hline USGS 77 & 137.4 & 95.4 & $0.586 \pm 0.0193$ & $0.71 \pm 0.04$ & 37.6 & 40.4 & $2.5 \pm 0.7$ & $1.1 \pm 0.7$ \\
\hline USGS 113 & 141 & 61.6 & $0.72 \pm 0.051$ & $0.75 \pm 0.04$ & 66.6 & 36.4 & $10.2 \pm 0.8$ & $10.3 \pm 1$ \\
\hline USGS 116 & 104 & 102 & $0.069 \pm 0.0026$ & $0.144 \pm 0.005$ & 30.1 & 32.8 & $0.5 \pm 0.5$ & $0.6 \pm 0.7$ \\
\hline
\end{tabular}

${ }^{1}$ Data from April 2003.

\section{Vertical Distribution of lodine-129 in the Snake River Plain Aquifer}

During September and October 2007, water samples were collected from 31 zones from 6 wells equipped with multi-level Westbay ${ }^{\mathrm{TM}}$ packer sampling systems (Middle 2050A, 2051, USGS 103, 132, 133, and 134; figs. 2 and $\underline{3}$ ). The Westbay ${ }^{\mathrm{TM}}$ systems isolate various zones of the aquifer so the vertical distribution of ${ }^{129} \mathrm{I}$ can be determined. Water from all but one of the sampled zones contained concentrations that were greater than the reporting level of $3 \mathrm{~s}$, and concentrations ranged from $0.00001 \pm 0.0000005$ to $0.0167 \pm 0.0007 \mathrm{pCi} / \mathrm{L}$ (table 2). All concentrations were greater than the estimated background concentration of $0.0000054 \mathrm{pCi} / \mathrm{L}$ for the ESRP aquifer as calculated by Cecil and others (2003). Three wells (USGS 103, 134 and Middle 2051) showed variability of one to two orders of magnitude in ${ }^{129} \mathrm{I}$ concentrations among various zones. Two of the wells (USGS 132 and 133) had one zone with a concentration that differed by more than one order of magnitude from their other zones, and one well (Middle 2050A) showed a similar concentration in all five zones (table 2). Concentrations were well below the MCL in all zones. 
Iodine-129 data collected by the USGS in September 2007 for three wells (Middle 2050A, Middle 2051, and USGS 132) also were sampled during 2005 and 2007 by the site contractor (table 2). Those samples were analyzed using the same laboratory and the same methods (U.S. Department of Energy, 2007, 2008). The data collected in 2007 from USGS 132 indicated similar concentrations; however, data from Middle 2050A and Middle 2051 collected by the contractor in 2005 were about one order of magnitude lower than 2007 USGS data in most of the zones. The samples analyzed in 2005 were processed as low-level samples, and they were not diluted in the chemical process (Mike Roddy, CH2M-WG Idaho (CWI), oral commun., May 15, 2008). The USGS samples were diluted, and rerun results for several of the samples in 2007 generally indicated that non-diluted samples produce results an order of magnitude smaller than the diluted samples at the concentration levels detected in these wells (table 2)

The variability with some of the ${ }^{129}$ I concentrations with depth in one well is consistent with the variability of the water chemistry. For example, USGS 132, near the RWMC, showed relatively consistent concentrations for all five deeper zones of water (763.9-1,172.2 ft) for ${ }^{129} \mathrm{I}$, calcium, sodium, bicarbonate, chloride, oxygen and deuterium isotopes, and tritium (table 5). The upper zone $6(636.4 \mathrm{ft})$, however, showed much higher concentrations of sodium and chloride and lower concentrations of tritium and ${ }^{129}$ I than the other five zones, which indicated that the upper zone probably is derived from another source of recharge water.

Concentrations of ${ }^{129} \mathrm{I}$ in well Middle 2050A were consistently the same in all five zones, but calcium, chloride, and tritium concentrations were higher in the upper zone (zone 5) than the other samples (table 5). Tritium and chloride concentrations in zone 5 probably can be attributed to local recharge associated with wastewater disposal.

$\mathrm{An}^{129} \mathrm{I}$ concentration of $0.000013 \pm 0.0000008 \mathrm{pCi} / \mathrm{L}$ was measured in water from well Middle 2051 in the upper zone of the aquifer (zone 5) that was one order of magnitude lower than the next two zones (zones 3 and 4) and two orders of magnitude lower than the two deepest zones (zones 1 and 2, table 5). The lower ${ }^{129} \mathrm{I}$ concentration in the upper zone, along with a tritium concentration that is less than the reporting level, indicates that this zone of water probably is not influenced by wastewater disposal. The chemical content of water from this zone is similar to Big Lost River drainage water (Carkeet and others, 2001) with low concentrations of sodium and chloride, a higher concentration of calcium, and heavier concentrations of oxygen and deuterium than water in the other zones. This well is near the Big Lost River, and the upper zone probably is influenced by Big Lost River recharge. Tritium concentrations in the other four zones are greater than the reporting level, so the water chemistry probably is influenced by wastewater disposal; however, the variability of the ${ }^{129} \mathrm{I}$ between zones also may be related to the same hydrologic processes that cause changes in piezometric head. Piezometric head decreases dramatically between the upper zone 5 and zones 3 and 4 (fig. 8), possibly due to the presence of a sedimentary interbed. Another interbed between zones 2 and 3 may increase head in the lower two zones, which also corresponds with an increase in the ${ }^{129} \mathrm{I}$ concentrations.

$\mathrm{A}^{129} \mathrm{I}$ concentration $(0.0011 \pm 0.00024 \mathrm{pCi} / \mathrm{L})$ in water from well USGS 133 in the upper zone of the aquifer (zone 4) was more than one order of magnitude larger than the other three zones. The water chemistry data for zone 4 is similar to zones 2 and 3, and all three upper zones differ from the deepest zone (zone 1; table 5). The ${ }^{129}$ I concentration in the upper zone of well USGS 133 is well above background, and because the well is upgradient of the INTEC, more research is needed to understand the source of this concentration.

The greatest concentration of ${ }^{129} \mathrm{I}(0.0012 \pm$ $0.00004 \mathrm{pCi} / \mathrm{L}$ ) in water from well USGS 103 was in the deepest zone (tables 2 and $\underline{5}$ ). The concentration also corresponded to the largest tritium concentration in this well (table 5), which indicated that water from the deepest zone is partially related to wastewater disposal. The concentrations of tritium and ${ }^{129}$ I support the concept introduced in Ackerman and others (2006) that wastewater introduced near the INTEC and the RTC in the upper part of the aquifer deepens at the southern part of the INL. 
Table 5. Concentrations of selected chemicals at multiple aquifer depths, Idaho National Laboratory, Idaho.

[Well locations are shown in figures 2 and $\underline{3}$. Port depth: feet below land surface. QAI-3 is a replicate of Middle 2051 Zone 2. QAI-4 is an equipment blank of inorganic free water. QAW-7 is a replicate of USGS 134 zone 4. QAW-8 is a replicate of Middle 2051 zone 4. Abbreviations: pCi/L, picocuries per liter, uncertainty is 1 standard deviation; $\mathrm{mg} / \mathrm{L}$, milligram per liter; USGS, U.S. Geological Survey; NS, not sampled; QAI, quality assurance iodine; NA, not applicable; QAW, quality assurance water. Rerun results used for all applicable iodine-129 concentrations]

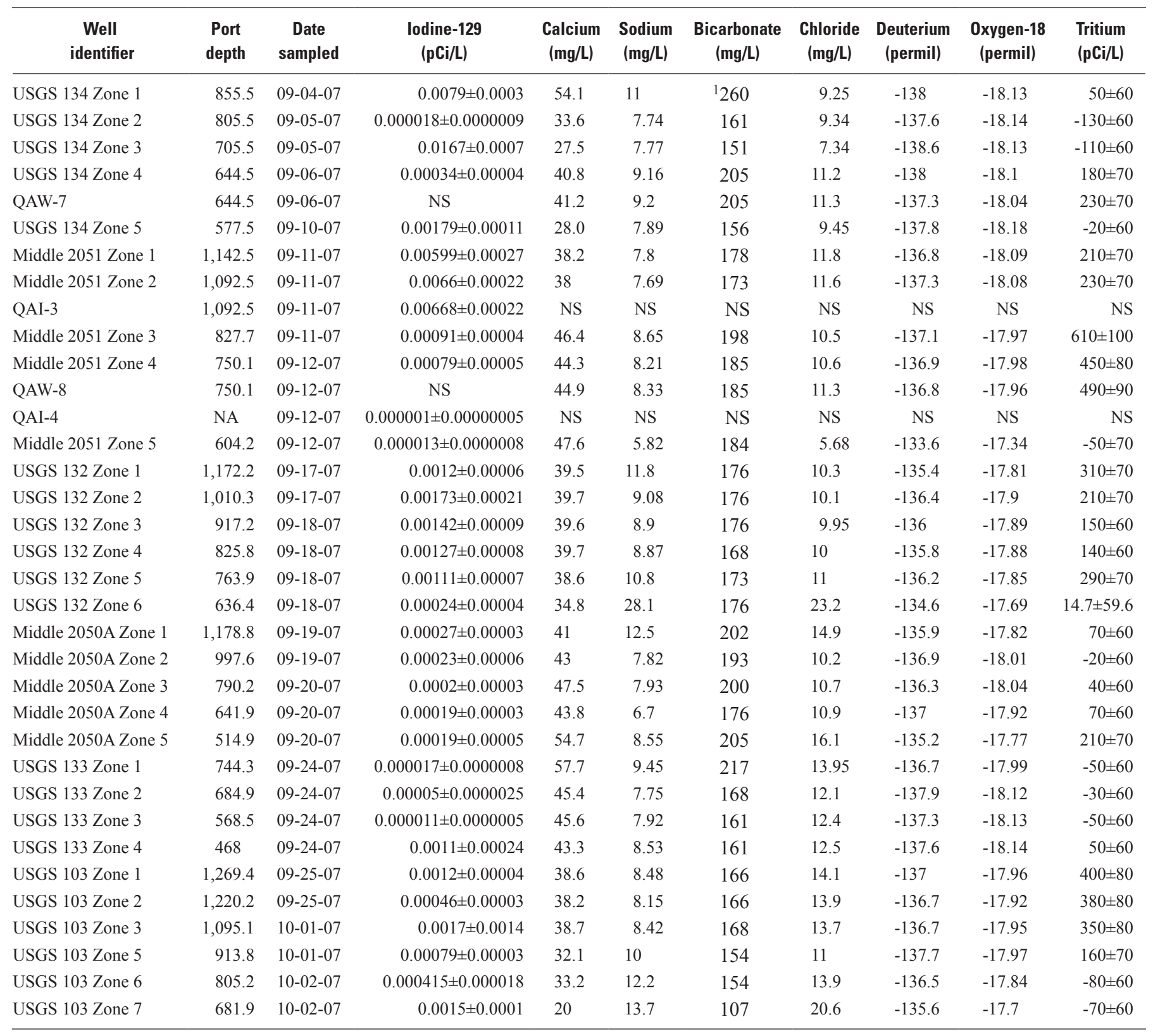

\footnotetext{
${ }^{1}$ Concentration from laboratory; field measurement not taken.
} 


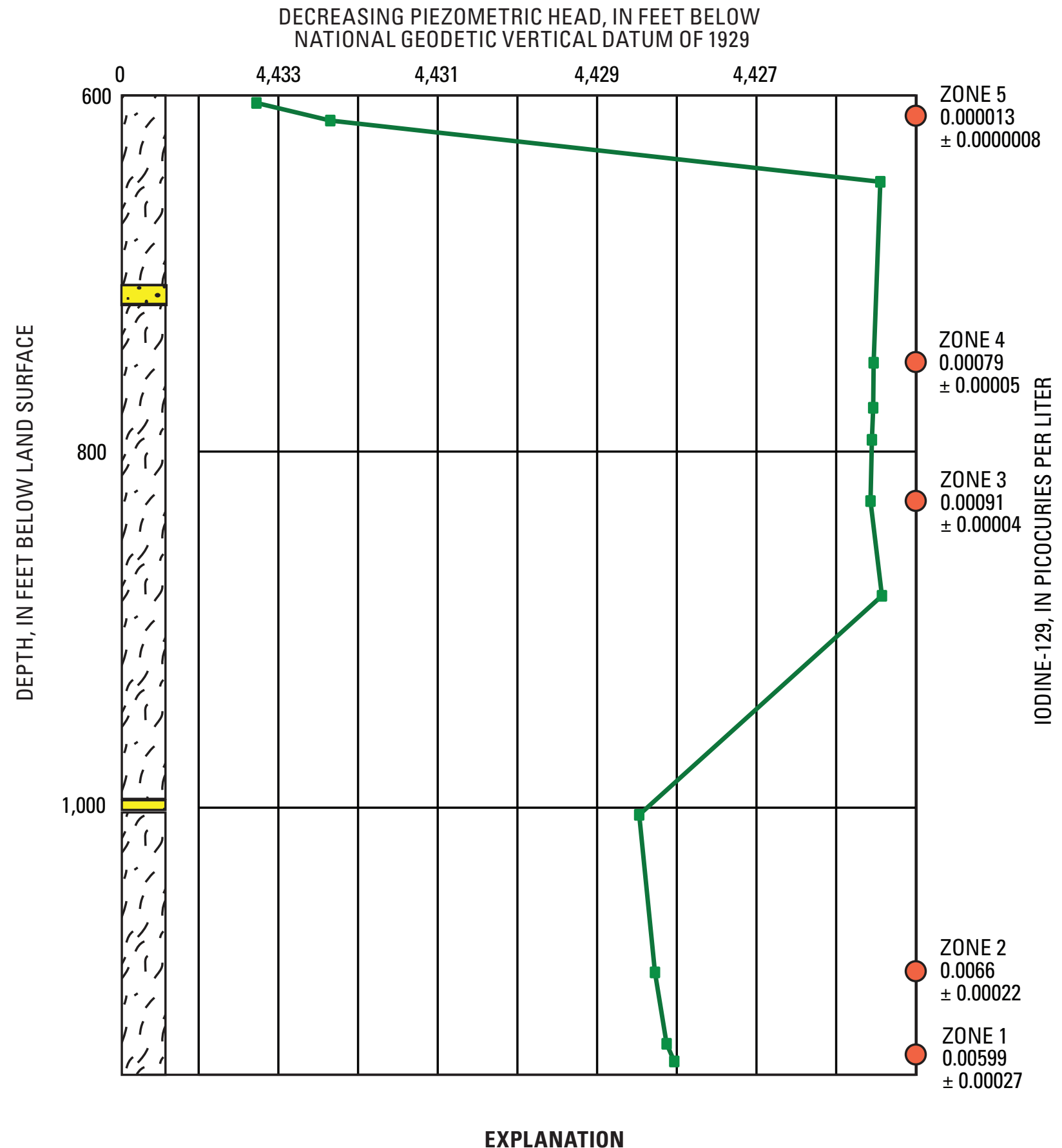

T, T Basalt-Yellow areas indicate sediment.

- Port where piezometric head was measured

Water sample collection zone

Figure 8. Concentrations of iodine-129 in well Middle 2051 in relation to piezometric head, Idaho National Laboratory, Idaho, 2007. 


\section{Summary}

From 1953 to 1988 , wastewater containing approximately 0.94 curies of iodine-129 $\left({ }^{129} \mathrm{I}\right)$ was generated at the Idaho National Laboratory (INL) in southeastern Idaho. Almost all this wastewater was discharged at or near the Idaho Nuclear Technology and Engineering Center (INTEC) on the INL site. Most of the wastewater was discharged directly into the eastern Snake River Plain aquifer through a deep disposal well until 1984; however, some wastewater also was discharged into unlined infiltration ponds or leaked from distribution systems below the INTEC.

The U.S. Geological Survey (USGS) conducted monitoring programs for ${ }^{129} \mathrm{I}$ in the Snake River Plain aquifer at the INL in $1977,1981,1986$, and 1990-91 prior to sample collection in 2003 and 2007. Some additional sampling was done in the 1990s to determine an estimated background concentration of eastern Snake River Plain aquifer water of 0.0000054 picocuries per liter (pCi/L). Current ${ }^{129} \mathrm{I}$ concentrations in the Snake River Plain aquifer at the INL are compared to the background concentration and to the U.S. Environmental Protection Agency's (USEPA) maximum contaminant level (MCL) of $1 \mathrm{pCi} / \mathrm{L}$.

In 2003, the USGS, in cooperation with the U.S. Department of Energy, collected samples for ${ }^{129}$ I from 36 wells that are used to monitor the Snake River Plain aquifer and from 1 well that is used to monitor a perched zone at the INTEC. Four replicate samples were collected as a measure of quality assurance. Concentrations of ${ }^{129} \mathrm{I}$ in the aquifer ranged from $0.0000066 \pm 0.0000002$ to $0.72 \pm 0.051 \mathrm{pCi} / \mathrm{L}$, and concentrations generally decreased in wells near the INTEC from samples collected during 1990-91. The average concentration of 19 wells sampled in both sample periods decreased from $0.975 \mathrm{pCi} / \mathrm{L}$ in $1990-91$ to $0.249 \mathrm{pCi} / \mathrm{L}$ in 2003. Many wells within a 3-mile radius of the INTEC showed decreases of as much as one order of magnitude in concentration, and all samples had concentrations less than the USEPA's MCL. These decreases are attributed to the discontinuation of disposal of ${ }^{129} \mathrm{I}$ in wastewater after 1988 and to dilution and dispersion in the aquifer.

Although wells near the INTEC sampled in 2003 showed decreases in concentrations compared with data collected in 1990-91, some wells south and east of the Central Facilities Area, near the site boundary, and south of the INL showed slight increases. These slight increases may be related to variable discharge rates of wastewater that eventually have moved to these well locations as a mass of water from a particular disposal period.

In 2007, the USGS collected water samples for ${ }^{129}$ I from 36 wells that are used to monitor the aquifer south of the INTEC and from 2 wells that are used to monitor perched zones at the INTEC. Concentrations of ${ }^{129} \mathrm{I}$ in the ESRP aquifer ranged from $0.000026 \pm 0.000002$ to
$1.16 \pm 0.04 \mathrm{pCi} / \mathrm{L}$, and a concentration that exceeded the MCL for public drinking water supplies was measured in one well. The average ${ }^{129} \mathrm{I}$ concentration in water from 19 wells sampled during 2003 and 2007 stayed about the same, but slight increases and decreases in several areas around the INTEC were evident in the aquifer. The decreases are attributed to the discontinued disposal of ${ }^{129} \mathrm{I}$ and to dilution and dispersion in the aquifer. The increases may be due to the movement into the aquifer of remnant perched water below the INTEC.

In 2007, the USGS also collected samples from 31 zones in 6 wells equipped with multi-level Westbay ${ }^{\mathrm{TM}}$ packer sampling systems to help define the vertical distribution of ${ }^{129} \mathrm{I}$ in the aquifer. Concentrations ranged from $0.000011 \pm$ 0.0000005 to $0.0167 \pm 0.0007 \mathrm{pCi} / \mathrm{L}$. Three wells showed variability of one to two orders of magnitude of concentrations of ${ }^{129} \mathrm{I}$ among various zones. Two wells included one zone with a concentration that differed by more than one order of magnitude from the other zones, and one well showed a similar concentration of ${ }^{129} \mathrm{I}$ in all five zones sampled. Concentrations were well below the MCL in all zones.

\section{Acknowledgments}

The author gratefully acknowledges efforts by Gordon Rattray of the USGS in compiling initial information for inclusion in this report, and by the USGS INL hydrologic technicians, led by Betty Tucker, for sample collection. The author is also grateful to Susan Ma of PRIME Lab for assistance provided with the analytical methods and calculations used for the results.

\section{References Cited}

Ackerman, D.J., 1991, Transmissivity of the Snake River Plain aquifer at the Idaho National Engineering Laboratory, Idaho: U.S. Geological Survey Water-Resources Investigations Report 91-4058 (DOE/ID-22097), 35 p.

Ackerman, D.J., Rattray, G.W., Rousseau, J.P., Davis, L.C., and Orr, B.R., 2006, A conceptual model of ground-water flow in the eastern Snake River Plain aquifer at the Idaho National Laboratory and vicinity with implications for contaminant transport: U.S. Geological Survey Scientific Investigations Report 2006-5122 (DOE/ID-22198), 62 p. Available at http://pubs.usgs.gov/sir/2006/5122.

Barraclough, J.T., Lewis, B.D., and Jensen, R.G., 1982, Hydrologic conditions at the Idaho National Engineering Laboratory, Idaho, emphasis 1974-1978: U.S. Geological Survey Water Supply Paper 2191, 52 p. 
Bartholomay, R.C., 1993, Concentrations of tritium and strontium-90 in water from selected wells at the Idaho National Engineering Laboratory after purging one, two, and three borehole volumes: U.S. Geological Survey WaterResources Investigations Report 93-4201 (DOE/ID-22111), $21 \mathrm{p}$.

Bartholomay, R.C., Knobel, L.K., and Rousseau, J.P., 2003, Field methods and quality-assurance plan for quality-ofwater activities, U.S. Geological Survey, Idaho National Engineering and Environmental Laboratory, Idaho: U.S. Geological Survey Open-File Report 03-42 (DOE/ ID-22182), $45 \mathrm{p}$.

Bartholomay, R.C., Tucker, B.J., Ackerman, D.J., and Liszewski, M.J., 1997, Hydrologic conditions and distribution of selected radiochemical and chemical constituents in water, Snake River Plain aquifer, Idaho National Engineering Laboratory, Idaho, 1992 through 1995: U.S. Geological Survey Water-Resources Investigations Report 97-4086 (DOE/ID-22137), 57 p.

Beasley, T.M., Dixon, P.R., and Mann, L.J., 1998, Technetium-99, uranium-236, and neptunium-237 in the Snake River Plain aquifer at the Idaho National Engineering and Environmental Laboratory, Idaho Falls, Idaho: Environmental Science and Technology, v. 32, p. 38753881 .

Brennan, T.S., Lehmann, A.K., and O'Dell, I., 2006, Water resources data, Idaho, 2005, volume 1-Surface-water records: U.S. Geological Survey Water Data Report ID-05-1, $510 \mathrm{p}$.

Busenberg, Eurybiades, Plummer, L.N., and Bartholomay, R.C., 2001, Estimated age and source of the young fraction of ground water at the Idaho National Engineering and Environmental Laboratory: U.S. Geological Survey WaterResources Investigations Report 01-4265 (DOE/ID-22177), $144 \mathrm{p}$.

Cahn, L.S., Abbott, M.L., Keck, J.F., Martian, Peter, Schafer, A.L., and Swenson, M.C., 2006, Operable unit 3-14 Tank Farm soil and groundwater remedial investigation/ baseline risk assessment: U.S. Department of Energy Idaho Operations Office Publication, DOE/NE-ID-11227, rev. 0, [variously paginated].

Carkeet, Colleen, Rosentreter, J.J., Bartholomay, R.C., and Knobel, L.L., 2001, Geochemistry of the Big Lost River drainage basin, Idaho: U.S. Geological Survey WaterResources Investigations Report 01-4031 (DOE/ID-22174), $31 \mathrm{p}$.
Cecil, L.D., Hall, L.F., and Green, J.R., 2003, Reevaluation of background iodine-129 concentrations in water from the Snake River Plain aquifer, Idaho, 2003: U.S. Geological Survey Water-Resources Investigations Report 03-4106 (DOE/ID-22186), 18 p.

Cecil, L.D., Welhan, J.A., Green, J.R., Frape, S.K., and Sudicky, E.R., 2000, Use of chlorine-36 to determine regional-scale aquifer dispersivity, eastern Snake River Plain aquifer, Idaho/USA: Nuclear Instruments and Methods in Physics Research, Section B 172, p. 679-687.

Claassen, H.C., 1982, Guidelines and techniques to obtain valid ground-water quality samples: U.S. Geological Survey Open-File Report 82-1024, 54 p.

Currie, L.A., 1984, Lower limit of detection-definition and elaboration of a proposed position for radiological effluent and environmental measurements: U.S. Nuclear Regulatory Commission NUREG/CR-4007, 139 p.

Davis, L.C., 2006, An update of hydrologic conditions and distribution of selected constituents in water, Snake River Plain Aquifer, Idaho National Laboratory, Idaho, emphasis 1999-2001: U.S. Geological Survey Scientific Investigations Report 2006-5088 (DOE/ID-22197), 48 p. Available at http://pubs.usgs.gov/sir/2006/5088/.

Duke, C.L., Roback, R.C., Reimus, P.W., Bowman, R.S., McLing, T.L., Baker, K.E., and Hull, L.C., 2007, Elucidation of flow and transport processes in a variably saturated system of interlayered sediment and fractured rock using tracer tests: Vadose Zone Journal, v. 6, no. 4, p. 855-867.

EG\&G Idaho, Inc., 1979, Radioactive waste management information for 1978: U.S. Department of Energy Report IDO-10055(78), $291 \mathrm{p}$.

Forbes, J.R., Ansley, S.L., and Leecaster, Molly, 2007, INTEC groundwater monitoring report (2006): U.S. Department of Energy, Idaho Operations Office Publication, DOE/ID-11301, rev. 0, 134 p.

Garabedian, S.P., 1986, Application of a parameter-estimation technique to modeling the regional aquifer underlying the eastern Snake River Plain, Idaho: U.S. Geological Survey Water Supply Paper 2278, 60 p.

Hall, L.F., 2006, Concentrations of selected trace metals, common ions, nutrients, and radiological analytes in ground water from selected sites, Snake River Plain aquifer, south of the Idaho National Laboratory, Idaho: State of Idaho Department of Environmental Quality Division of INL Oversight and Radiation Control, OP-06-03, 28 p. 
Knobel, L.L., 2006, Evaluation of well-purging effects on water-quality results for samples collected from the Eastern Snake River Plain aquifer underlying the Idaho National Laboratory, Idaho: U.S. Geological Survey Scientific Investigations Report 2006-5232 (DOE/ID-22200), 52 p. Available at http://pubs.usgs.gov/sir/2006/5232/.

Lewis, B.D., and Jensen, R.G., 1985, Hydrologic conditions at the Idaho National Engineering Laboratory, Idaho-19791981 update: U.S. Geological Survey Open-File Report 84-230 (IDO-22066), 65 p.

Litteer, D.L., 1988, Idaho National Engineering Laboratory radioactive waste management information for 1987: U.S. Department of Energy, Waste Management Programs Division, Idaho Operations Office Publication, DOE/ ID-10055 (87), $530 \mathrm{p}$.

Litteer, D.L., and Reagan, B.D., 1989, Idaho National Engineering Laboratory radioactive waste management information for 1988: U.S. Department of Energy, Waste Management Programs Division, Idaho Operations Office Publication, DOE/ID-10055 (88), 510 p.

Mann, L.J., 1986, Hydraulic properties of rock units and chemical quality of water for INEL-1-A 10,365-foot deep test hole drilled at the Idaho National Engineering Laboratory, Idaho: U.S. Geological Survey Water-Resources Investigations Report 86-4020 (DOE/ID-22070), 23 p.

Mann, L.J., and Beasley, T.M., 1994a, Background concentrations of ${ }^{129} \mathrm{I}$ in ground and surface water, eastern Snake River Plain, Idaho-1992: Journal of the Idaho Academy of Sciences, v. 30 no. 2, p. 75-87.

Mann, L.J., and Beasley, T.M., 1994b, Iodine-129 in the Snake River Plain aquifer at the Idaho National Engineering Laboratory, Idaho, 1990-1991: U.S. Geological Survey Water-Resources Investigations Report 94-4053 (DOE/ ID-22115), $27 \mathrm{p}$.

Mann, L.J., Chew, E.W., Morton, J.S., and Randolph, R.B., 1988, Iodine-129 in the Snake River Plain aquifer at the Idaho National Engineering Laboratory, Idaho: U.S. Geological Survey Water-Resources Investigations Report 88-4165 (DOE/ID-22076), 27 p.

Nimmo, J.R., Perkins, K.S., Rose, P.A., Rousseau, J.P., Orr, B.R., Twining, B.V., and Anderson, S.R., 2002, Kilometerscale rapid transport of naphthalene sulfonate tracer in the unsaturated zone at the Idaho National Engineering and Environmental Laboratory: Vadose Zone Journal, v. 1, p. 89-101.
Rao, Usha, 1997, Sources, reservoirs and pathways of anthropogenic 129I in western New York: Rochester, New York, University of Rochester, PhD. Dissertation, 147 p.

Robertson, J.B., Schoen, Robert, and Barraclough, J.T., 1974, The influence of liquid waste disposal on the geochemistry of water at the National Reactor Testing Station, Idaho-1952-1970: U.S. Geological Survey Open-File Report 73-238 (IDO-22053), $231 \mathrm{p}$.

Sharma, Pankaj, Elmore, David, Miller, Thomas, and Vogt, Stephan, 1997, The ${ }^{129}$ I AMS program at PRIME lab: Proceedings of Section B of Nuclear Instruments and Methods, v. 123, p. 347-351.

Taylor, J.K., 1987, Quality assurance of chemical measurements: Chelsea, Mich., Lewis Publishers, 328 p.

U.S. Department of Energy, 2004, Monitoring report decision summary for operable unit 3-13, group 5, Snake River Plain aquifer: U.S. Department of Energy Idaho Operations Office Publication, DOE/ID-11098, rev. 1, variously paginated.

U.S. Department of Energy, 2007, Waste area group 10, operable unit 10-08, remedial investigation/feasibility study annual status report for fiscal year 2006: U.S. Department of Energy Idaho Operations Office Publication, DOE/ID-11297, rev. 0, 245 p.

U.S. Department of Energy, 2008, Waste area group 10, operable unit 10-08, annual monitoring status report for fiscal year 2007: U.S. Department of Energy Idaho Operations Office Publication, DOE/ID-11355, rev. 0, 123 p.

U.S. Environmental Protection Agency, 1976, National interim primary drinking water regulations: U.S. Environmental Protection Agency, Office of Water Supply, EPA-570/9-76003, variously paged.

U.S. Environmental Protection Agency, 2000, Radionuclides notice of data availability technical support document: U.S. Environmental Protection Agency, Targeting and Analysis Branch, Standards and Risk Management Division, Office of Ground Water and Drinking water, 164 p., accessed February 5, 2008, at http://www.epa.gov/safewater/ radionuclides/pdf/regulation_radionuclides_rulemaking techsupportdoc.pdf

U.S. Geological Survey, 1985, National water summary, 1984-hydrologic events, selected water-quality trends, and ground-water resources: U.S Geological Survey WaterSupply Paper 2275, $467 \mathrm{p}$. 
U.S. Geological Survey, 2006, Water-resources data for the United States-Water year 2006: U.S. Geological Survey database. Available at http://wdr.water.usgs.gov/.

U.S. Geological Survey, variously dated, National field manual for the collection of water-quality data: U.S. Geological Survey Techniques of Water-Resources Investigations, Book 9, Chapters A1-A9. Available at http://pubs.water. usgs.gov/twri9A

Volk, William, 1969, Applied statistics for engineers (2d ed.): New York, McGraw-Hill Book Company, 415 p.
Williams, L.M., 1996, Evaluation of quality assurance/quality control data collected by the U.S. Geological Survey for water-quality activities at the Idaho National Engineering Laboratory, Idaho, 1989 through 1993: U.S. Geological Survey Water-Resources Investigations Report 96-4148 (DOE/ID-22129), $116 \mathrm{p}$.

Wood, W.W., 1981, Guidelines for collection and field analysis of ground-water samples for selected unstable constituents: U.S. Geological Survey Techniques of Water-Resources Investigations, Book 1, Chapter D2, 24 p. 
This page intentionally left blank. 
Publishing support provided by the U.S. Geological Survey Publishing Network, Tacoma Publishing Service Center

For more information concerning the research in this report, contact the Director, Idaho Water Science Center

U.S. Geological Survey

230 Collins Road

Boise, Idaho 83702

http://id.water.usgs.gov 
